\title{
Expedition 319 summary ${ }^{1}$
}

\author{
Expedition 319 Scientists $^{2}$
}

\section{Chapter contents}

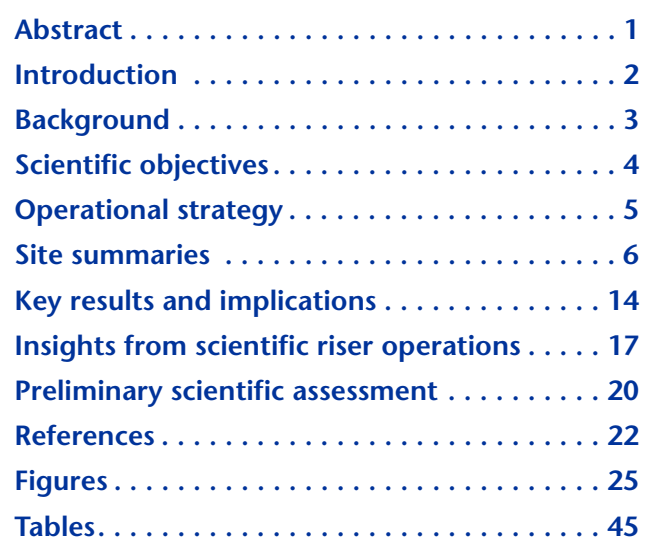

'Expedition 319 Scientists, 2010. Expedition 319 summary. In Saffer, D., McNeill, L., Byrne, T., Araki, E., Toczko, S., Eguchi, N., Takahashi, K., and the Expedition 319 Scientists, Proc. IODP, 319: Tokyo (Integrated Ocean Drilling Program Management International, Inc.).

doi:10.2204/iodp.proc.319.101.2010

'Expedition 319 Scientists' addresses.

\section{Abstract}

The Nankai Trough Seismogenic Zone Experiment (NanTroSEIZE) is a coordinated, multiexpedition drilling project designed to investigate fault mechanics and seismogenesis along subduction megathrusts through direct sampling, in situ measurements, and long-term monitoring in conjunction with allied laboratory and numerical modeling studies. The fundamental scientific objectives of the NanTroSEIZE project include characterizing the nature of fault slip and strain accumulation, fault and wall rock composition, fault architecture, and state variables throughout the active plate boundary system. As part of the NanTroSEIZE program, operations during Integrated Ocean Drilling Program (IODP) Expedition 319 included riser drilling, analyses of cuttings and core samples, downhole measurements and logging, and casing at Site C0009 in the Kumano forearc basin as well as riserless drilling, logging while drilling (LWD), casing, and observatory operations at Site C0010 across a major splay fault (termed the "megasplay") that bounds the seaward edge of the forearc basin near its updip terminus. In addition, we drilled at contingency Site C0011 to collect LWD data in advance of planned coring operations scheduled for IODP Expedition 322.

Site C0009 marked the first riser drilling in IODP history. This allowed several scientific operations unprecedented in IODP, including carefully controlled measurements of in situ pore pressure, permeability and minimum principal stress magnitude, real-time mud gas analysis, and laboratory analyses of cuttings. We conducted a leak-off test at one depth interval and successfully deployed the wireline Modular Formation Dynamics Tester 12 times to directly measure in situ stress magnitude, formation pore pressure, and permeability. During all phases of riser drilling, we sampled mud gas for geochemical analyses, and cuttings samples were collected throughout the entire riser-drilled depth range. Integration of data from cuttings, wireline logging, and cores (from a limited depth interval at the base of the hole) allowed definition of a single integrated set of lithologic units and comparison with previously drilled IODP Site C0002 to constrain the history of the forearc basin. After casing the borehole, we also conducted a long-offset (up to $30 \mathrm{~km}$ ) two-ship active seismic experiment, recording shots within the borehole to image the megasplay and décollement beneath the borehole and to evaluate 
seismic velocity and anisotropy of the forearc basin and accretionary prism sediments around the borehole.

At riserless Site C0010, operations included drilling with LWD/measurement-while-drilling (MWD) tools across the megasplay fault to $555 \mathrm{mbsf}$, casing the borehole with screens across the fault zone, conducting an observatory dummy run to test future strainmeter and seismometer deployment procedures, and installation of a temporary pore pressure and temperature monitoring system in advance of planned future permanent observatory emplacement. The temporary observatory system (termed a "smart plug") marks the first observatory installation of the NanTroSEIZE program. LWD/MWD data at this site were used to define unit boundaries and the fault zone target interval for placement of the casing screens. Through comparison with previously drilled Site C0004 these data also provide insights into along-strike differences in the architecture of the megasplay fault and its hanging wall.

\section{Introduction}

\section{Overview of the NanTroSEIZE complex drilling project}

Subduction zones account for 90\% of global seismic moment release, generating damaging earthquakes and tsunamis with potentially disastrous effects on heavily populated coastal areas (e.g., Lay et al., 2005). Understanding the processes that govern the strength, nature, and distribution of slip along these plate boundary fault systems is a crucial step toward evaluating earthquake and tsunami hazards. More generally, characterizing fault slip behavior and mechanical state in a range of tectonic settings through direct sampling, near-field geophysical observations, and measurement of in situ conditions is a fundamental and societally relevant goal of modern earth science. To this end, several recent and ongoing drilling programs have targeted portions of active plate boundary faults that have slipped coseismically during large earthquakes or that have nucleated smaller events. These efforts include the San Andreas Fault Observatory at Depth (Hickman et al., 2004), the Taiwan-Chelungpu Drilling Project (Ma, 2005), and Nankai Trough Seismogenic Zone Experiment (NanTroSEIZE) ocean drilling project (Tobin and Kinoshita, 2006a, 2006b).

NanTroSEIZE is a multiexpedition, multistage Integrated Ocean Drilling Program (IODP) drilling project focused on understanding the mechanics of seismogenesis along subduction plate boundary faults. The drilling program includes a coordinated effort to characterize, sample, and instrument the plate boundary system at several locations offshore the Kii Peninsula, culminating in drilling, sampling, and instrumenting the plate boundary fault system near the updip limit of inferred coseismic slip $\sim 6-7 \mathrm{~km}$ below seafloor (Tobin and Kinoshita, 2006b) (Figs. F1, F2, F3). The main objectives are to understand:

- The mechanisms controlling the updip aseismicseismic transition along the megathrust fault system,

- Processes of earthquake and tsunami generation and strain accumulation and release,

- The absolute mechanical strength of the plate boundary fault, and

- The potential role of a major upper plate fault system (termed the "megasplay" fault) in seismogenesis and tsunamigenesis.

The drilling program will evaluate a set of overarching hypotheses through a combination of riser and riserless drilling, long-term observatories, and associated geophysical, laboratory, and numerical modeling efforts. The following hypotheses are paraphrased from the original IODP proposals and outlined in Tobin and Kinoshita (2006a, 2006b):

1. Systematic, progressive material and state changes control the onset of seismogenic behavior on subduction thrust faults.

2. Subduction megathrusts are weak faults.

3. Plate motion is accommodated primarily by coseismic frictional slip in a concentrated zone (i.e., the fault is locked during the interseismic period).

4. Physical properties of the plate boundary system (including the fault system and its hanging wall and footwall) change with time during the earthquake cycle.

5. A significant, laterally extensive upper plate fault system (the megasplay fault; Park et al., 2002) slips in discrete events, including great earthquakes, and may influence tsunami generation. It remains locked during the interseismic period and accumulates strain.

Sedimented subduction zones such as the East Aleutian, Cascadia, Sumatra, and Nankai margins are characterized by repeated great earthquakes of $\sim$ M 8.0+ (Ruff and Kanamori, 1983). Although the causative mechanisms are not well understood (e.g., Byrne et al., 1988; Moore and Saffer, 2001; Saffer and Marone, 2003), the updip limit of the seismogenic zones at these margins is thought to correlate with a topographic break, often associated with the outer rise (e.g., Byrne et al., 1988; Wang and $\mathrm{Hu}, 2006$ ). At Nankai, high-resolution seismic reflection profiles across the outer rise clearly document a large out-of- 
sequence thrust fault system (the megasplay fault, after Park et al., 2002) that branches from the plate boundary décollement close to the updip limit of inferred coseismic rupture in the 1944 Tonankai M 8.2 earthquake (Figs. F1B, F2). Several lines of evidence indicate that the megasplay system is active and may accommodate a significant fraction of plate boundary motion (e.g., Moore et al., 2007; Strasser et al., 2009). However, the partitioning of strain between the lower plate interface (the décollement zone) and the megasplay system, and the nature and mechanisms of fault slip as a function of depth and time on the megasplay, are not understood. One of the firstorder goals in characterizing the seismogenic zone along the Nankai Trough-and which bears both on understanding subduction zone megathrust behavior globally and on defining tsunami hazards-is to document the role of the megasplay fault in accommodating plate motion (both seismically and interseismically) and to characterize its mechanical and hydrologic behavior.

In late 2007 through early 2008, IODP Expeditions 314,315 , and 316 were carried out as a unified program of drilling, collectively known as NanTroSEIZE Stage 1. A transect of eight sites was selected for riserless drilling to target the frontal thrust region, the midslope megasplay fault region, and the Kumano forearc basin region (Fig. F3). Two of these sites were preparatory pilot holes for planned deeper riser drilling operations, and the others primarily targeted fault zones in the shallow, presumed aseismic portions of the accretionary complex (Kinoshita, Tobin, Ashi, Kimura, Lallemant, Screaton, Curewitz, Masago, Moe, and the Expedition 314/315/316 Scientists, 2009). Expedition 314 was dedicated to in situ measurement of physical properties and borehole imaging through logging while drilling (LWD) (Kinoshita et al., 2008). Expedition 315 was devoted to core sampling and downhole temperature measurements at a site in the megasplay region and one in the forearc basin (Ashi et al., 2008). Expedition 316 targeted the frontal thrust and megasplay fault in their shallow, aseismic portions (Ashi et al., 2008; Kimura et al., 2008).

NanTroSEIZE Stage 2 included two expeditions (319 and 322), with the aims of building on the results of Stage 1 and preparing for later observatory installations for long-term monitoring of deformation at the updip limit of the seismogenic zone. IODP Expedition 319 investigated the properties, structure, and state of stress within the hanging wall above the locked plate boundary at Site C0009 and across the shallow megasplay at Site C0010, and prepared boreholes for the future installation of observatories. IODP Expedition 322 sampled and characterized the properties of sediments on the subducting Philippine Sea plate. The initial results from Expedition 319 , described in detail here, include data and operations for two sites: Site C0009, a riser drilling site in the Kumano Basin, and Site C0010, a riserless site into the shallow megasplay fault near its updip terminus.

In future IODP expeditions, long-term borehole observatory installations are planned for the two boreholes drilled during Expedition 319. The boreholes are located within and above regions of contrasting behavior of the megasplay fault zone and plate boundary as a whole (i.e., a site $\sim 10 \mathrm{~km}$ above the locked seismogenic plate boundary [Site C0009] and a shallow site in the megasplay fault zone and footwall where slip is presumed to be aseismic [Site C0010]). These observatories have the potential of capturing seismic activity, slow slip behavior, hydraulic transients, and possibly interseismic strain accumulation on the megasplay fault and décollement. Currently, the planned observation system for the boreholes consists of an array of sensors designed to monitor slow crustal deformation (e.g., strain, tilt, and pore pressure as a proxy for strain), seismic events including very low frequency (VLF) earthquakes, hydrologic transients associated with strain events, ambient pore pressure, and temperature. These borehole observatories will be connected to the submarine cabled observation network Dense Oceanfloor Network System for Earthquakes and Tsunamis (DONET) (www.jamstec.go.jp/jamstec-e/ maritec/donet/), which will be constructed in and around the drilling target area.

\section{Background Geological setting}

The Nankai Trough is formed by northwestward subduction of the Philippine Sea plate beneath the Eurasian plate at a rate of $\sim 40-65 \mathrm{~mm} / \mathrm{y}$ (Seno et al., 1993; Miyazaki and Heki, 2001). The convergence direction is slightly oblique to the trench, and sediments of the Shikoku Basin are actively accreting at the deformation front. The Nankai Trough is among the most extensively studied subduction zones in the world, and great earthquakes during the past 3000 or more years are well documented in historical and archeological records (e.g., Ando, 1975). The Nankai Trough has been selected as a focus site for studies of seismogenesis by both IODP and the U.S. MARGINS initiative, based on the wealth of geological and geophysical data available, a long historical record of great $(M>8.0)$ earthquakes, and the direct societal relevance of understanding tsunamis and 
earthquakes that have had, and will have, great impact on nearby heavily populated coastal areas.

The Nankai Trough region has a historical record of recurring tsunamigenic great earthquakes, including the 1944 Tonankai M 8.2 and 1946 Nankaido M 8.3 earthquakes (Ando, 1975; Hori et al., 2004). The rupture area and zone of tsunami generation for the 1944 event are now reasonably well understood (Ichinose et al., 2003; Baba et al., 2005) (Fig. F1B). Landbased geodetic studies suggest that the plate boundary thrust is currently strongly locked (Miyazaki and Heki, 2001), and the relatively low level of microseismicity near the updip limits of the 1940s earthquakes (Obana et al., 2001) implies significant interseismic strain accumulation on the megathrust. However, recent observations of VLF earthquakes within or just below the accretionary prism in the drilling area (Obara and Ito, 2005) demonstrate that some strain release does occur during interseismic periods (Fig. F1B). Slow slip phenomena including episodic slow slip events and nonvolcanic tremor are also widely known to occur in the downdip part of the rupture zone (Ito et al., 2007).

The region offshore the Kii Peninsula on Honshu Island was selected for seismogenic zone drilling for several reasons. First, the rupture area of the most recent great earthquake, the 1944 Tonankai M 8.2 event, is well constrained by recent seismic and tsunami waveform inversions (e.g., Kikuchi et al., 2003; Tanioka and Satake, 2001). Slip inversion studies suggest that only in this region did past coseismic rupture clearly extend to sufficiently shallow depths to be reached by drilling (Ichinose et al., 2003; Baba and Cummins, 2005), and an updip zone of large slip has been identified and targeted (Fig. F1B). Notably, coseismic slip during events like the 1944 Tonankai earthquake may have occurred on the megasplay fault (Ichinose et al., 2003; Baba et al., 2006). The megasplay fault is therefore one of the primary drilling targets. Second, ocean-bottom seismometer (OBS) campaigns and onshore high-resolution geodetic studies (though of short duration) indicate significant interseismic strain accumulation (e.g., Miyazaki and Heki, 2001; Obana et al., 2001). Third, the region offshore the Kii Peninsula is generally typical of the Nankai margin in terms of heat flow and sediment on the incoming plate. This is in contrast to the area offshore Cape Muroto (the location of previous Deep Sea Drilling Project and Ocean Drilling Program [ODP] drilling) where both local stratigraphic variation associated with basement topography and anomalously high heat flow have been documented (Moore et al., 2001; Moore, Taira, Klaus, et al., 2001). Finally, the drilling targets are within the operational limits of riser drilling by $\mathrm{D} / \mathrm{V}$
Chikyu (i.e., maximum of $2500 \mathrm{~m}$ water depth and $7000 \mathrm{~m}$ subseafloor penetration). In the seaward portions of the Kumano Basin, the seismogenic zone lies $\sim 6-7 \mathrm{~km}$ beneath the seafloor (Nakanishi et al., 2002).

\section{Seismic studies/site survey data}

A significant volume of site survey data has been collected in the drilling area over many years, including multiple generations of two-dimensional seismic reflection (e.g., Park et al., 2002), wide-angle refraction (Nakanishi et al., 2002), passive seismicity (e.g., Obara et al., 2004), heat flow (Yamano et al., 2003), side-scan sonar, swath bathymetry, and submersible and remotely operated vehicle (ROV) dive data (Ashi et al., 2002). In 2006, Japan and the United States conducted a joint three-dimensional (3-D) seismic reflection survey over a $\sim 11 \mathrm{~km} \times 55 \mathrm{~km}$ area, acquired by PGS Geophysical, an industry service company (Fig. F3). This 3-D data volume has been used to refine selection of drill sites and targets in the complex megasplay fault region, define the 3-D regional structure and seismic stratigraphy, analyze physical properties of the subsurface, and assess drilling safety (Moore et al., 2007, 2009).

\section{Scientific objectives}

Expedition 319 was noteworthy because it marked the first riser drilling in IODP history, as well as the first observatory installation for the Chikyu. Riser drilling provided the opportunity for several measurements new to IODP, including in situ stress magnitude and pore pressure using the Modular Formation Dynamics Tester (MDT) wireline tool, real-time mud gas analysis, and analysis of drill cuttings. In addition, the operations plan included a leak-off test (LOT) at a casing set point for engineering purposes, which provided an additional measurement of minimum stress magnitude. Our operational and scientific plan also included a long-offset $(30 \mathrm{~km})$ "walkaway" vertical seismic profile (VSP) at the riser Site C0009 and the first installation of long-term borehole monitoring instruments by the Chikyu using a simple instrument package (smart plug) connected to a retrievable casing packer at the riserless Site C0010 (Araki et al., 2009).

Our objectives at Site C0009 were to drill, sample, log, and case the rocks and sediments above the locked portion of the coseismically active plate boundary thrust (Fig. F4A; see also Figs. F1, F2, F3). These operations also provide preparation for later observatory placement, which will monitor deformation, seismicity, pore pressure, and 
temperature. The scientific objectives at Site C0009 included:

1. Documenting the lithology, structural geology, physical properties, and fluid and rock composition of the upper $\sim 1600 \mathrm{~m}$ of basin fill and possibly accreted sediments in the hanging wall of the plate boundary fault;

2. Collecting core at or near the depth of potential observatory installation, primarily to obtain samples for shore-based geotechnical and mechanical analyses;

3. Conducting downhole tests to measure in situ pore pressure and stress state; and

4. Conducting a two-ship VSP experiment to constrain the seismic velocity structure of the deep interior of the accretionary wedge and image the plate boundary below the drill site.

At Site C0010, our objective was to drill with measurement while drilling (MWD) and a basic suite of LWD tools (geoVISION resistivity tool [GVR] and gamma ray) to penetrate the megasplay fault at $\sim 410$ meters below seafloor (mbsf) and into the footwall to a total depth (TD) of 560 mbsf (Fig. F4B). The major scientific objectives at Site C0010 included:

1. Characterizing the lithology, structural geology, and physical properties of the hanging wall, megasplay fault zone, and footwall using logging data;

2. Correlating between Site C0010 and previously drilled IODP Site C0004 ( 3.5 km along strike) to characterize local variations in fault zone architecture and physical properties;

3. Conducting a "dummy run" of a seismometer and strainmeter package designed for placement in a future permanent observatory at this site; and

4. Installing a temporary monitoring package to monitor pore pressure and temperature within the fault zone accessed through a screened casing.

\section{Operational strategy}

Our drilling plan for Expedition 319 included one riser borehole in the Kumano Basin at proposed Site NT2-11B (drilled Site C0009; Fig. F4A) and one riserless hole at proposed Site NT2-01J (drilled Site C0010; Fig. F4B).

To meet the scientific and engineering objectives, primary operations at both sites were to drill and case to TD (Araki et al., 2009). Because of anticipated challenges and uncertainty in operations schedules with both riser and riserless operations, we also developed a detailed suite of contingency operations for the expedition. Our primary contingency operations included installing casing and temporary observatory instruments at IODP Site C0002 (Araki et al., 2009) and drilling and coring proposed Site NT101 in the Shikoku Basin planned for Expedition 322 (Saito et al., 2009) (Fig. F3).

Planned operations at Site C0009 began with running and jetting-in a 36 inch conductor casing to 55 mbsf. Following this, the wellhead was to be set at the seafloor, and a 26 inch riserless hole drilled to 700 mbsf with MWD, including annular pressure while drilling. After installing and cementing 20 inch casing in the upper $700 \mathrm{~m}$, the planned operations were to lower the blowout preventer, connect it at the wellhead, drill a $12^{1 / 4}$ inch riser hole from 700 to 1510 mbsf with MWD, including recovery and analysis of cuttings, and then rotary core barrel (RCB) core from 1510 to 1600 mbsf. After coring and opening the cored hole to $12 \frac{1}{4}$ inches, three wireline logging runs were planned from $~ 700$ to $\sim 1600$ mbsf: (1) the Schlumberger Platform Express, including the Highly Integrated Gamma Ray Neutron Sonde, Three-Detector Lithology Density tool, and HighResolution Laterolog Array; (2) Formation MicroImager (FMI) and Sonic Scanner; and (3) MDT. After wireline logging, the hole was to be opened to 17 inches and cased to TD with $13 \% 8$ inch casing. Drilling mud gas collection was planned during all riser drilling operations. After cementing the casing, a cement-bond $\log (\mathrm{CBL})$ was planned inside the casing, followed by a zero-offset VSP and a two-ship walkaway and circular VSP experiment coordinated with the Japan Agency for Marine-Earth Science and Technology (JAMSTEC) R/V Kairei. The VSP experiment was planned for 2 or more days, but the duration depended on operational progress and the drilling schedule. Following the VSP, we planned to suspend the riser hole by setting a corrosion cap, with a contingency plan to hang a short $(\sim 100 \mathrm{~m})$ thermistor string into the casing for later retrieval if time permitted.

We completed almost all of the planned scientific and engineering objectives at Site C0009, with riser operations ending on 31 July (as scheduled, including contingency days). Because of time constraints, the CBL was eliminated from operations. In addition, because of the combination of time constraints on the drilling schedule and limitations on the availability of the Kairei (shooting vessel), the planned two-ship VSP experiment was shortened slightly. A total of 19 contingency days were included in the original schedule and were fully used for recovery of a lost bottom-hole assembly (BHA)/drilling ahead tool (DAT) during riserless drilling, problems with the dynamic positioning system (DPS), mechanical 
problems related to riser system installation (riser tensioners and tensioner load ring), and weather. Some operations were considerably faster than scheduled, including the retrieval of the riser system after completion of riser drilling operations and installation of the 20 inch casing string.

Planned operations at proposed Site NT2-01J (drilled Site C0010) included jetting-in a 20 inch casing string to $35 \mathrm{mbsf}$, followed by hole reentry and drilling of a $12^{1 / 4}$ inch hole with MWD and a limited suite of LWD (GVR, including gamma ray and azimuthal resistivity-at-the-bit [RAB] measurement) to TD at 560 mbsf. After drilling, 95/8 inch casing with two screened casing joints ( 11 m long each) spanning the megasplay fault would be installed to $\sim 550$ mbsf, leaving an $\sim 10 \mathrm{~m}$ open "rathole." Based on seismic data, we estimated the depth of the megasplay fault at $\sim 410$ mbsf; we anticipated adjusting the exact depth for the casing screens shortly before running the casing, using the newly acquired LWD/ MWD data. After cementing the casing, we planned an observatory sensor dummy run to measure shock and acceleration experienced by highly sensitive strainmeter and seismometer instruments, in order to assess operations for future reentry and installation of observatory instruments, followed by a wireline temperature log inside the casing to identify the top of cement in the annulus. The hole was to be suspended by installing a retrievable casing packer modified to include the smart plug instrument package below at $\sim 390 \mathrm{~m}$ and setting a corrosion cap. The smart plug is designed to thread to a crossover joint at the bottom of the bridge plug and includes a selfcontained temperature sensor and data logger, as well as a pressure gauge and data logger package. These instruments will be in hydrologic communication with the fault zone at the screened interval and will monitor formation pore pressure and temperature from the time the bridge plug is set until it is retrieved (anticipated for 2010/2011).

We completed all of the planned operations at Site C0010, with the exception of the wireline temperature $\log$, which we eliminated to preserve time and after discussion with the operations group resolved that it would be of limited use to define the top of cement. In addition, drilling with LWD/MWD was suspended after reaching $482 \mathrm{~m}$ LWD depth below seafloor (LSF) (Table T1) in order to evacuate for a typhoon, and resumed after $\sim 2$ days. Based on poor data quality related to ship heave and stick-slip, after returning to the site and reentering the hole, we reamed and relogged a critical interval near the megasplay fault zone from 348 to 418 m LSF before running down to the previous TD and drilling with LWD/MWD to a TD of $555 \mathrm{~m} \mathrm{LSF}$.
In practice, our contingency options evolved during the expedition because of time constraints and the limited availability of personnel for coring operations. In response to these constraints, we developed additional contingency plans that would generate data of high value to the overall NanTroSEIZE drilling project. These operations included LWD/MWD at proposed Sites NT1-07 and NT1-01, which were the primary and contingency sites, respectively, for Expedition 322 (Saito et al., 2009). In the final 5 days of Expedition 319, we moved to Site C0011 (proposed Site NT1-07), dropped 6 transponders, and drilled with LWD/MWD to a TD of $952 \mathrm{~m} \mathrm{LSF}$. LWD data and results from Site C0011 are not described here but will be included in the Expedition 322 Preliminary Report (Underwood et al., 2009) and Proceedings, along with results of coring, downhole measurements, and wireline logging.

\section{Site summaries}

\section{Site C0009}

Site C0009 marked the first riser drilling in IODP history (Table $\mathrm{T} 2$ ). This provided the opportunity to conduct several scientific operations new to IODP, including measurements of in situ pore pressure and stress magnitude using the MDT tool and by LOT, real-time mud gas analysis, and laboratory analyses of cuttings. In situ pore pressure, stress magnitude, and permeability are among the most central data for understanding the mechanics of active fault zones and testing the core NanTroSEIZE hypotheses, but they have previously been unavailable in IODP drilling. Analyses of mud gas and cuttings, although common in other riser drilling programs (e.g., Erzinger et al., 2006), were also conducted for the first time in IODP and will be essential for future riserbased drilling. Because there are no standard IODP procedures for shipboard measurements on cuttings, the scientific party developed techniques for handling, sampling, and measurement of physical properties, rock chemistry, and sedimentological and structural description (see discussion in "Insights from scientific riser operations").

Drilling at Site C0009 achieved all of the primary planned scientific objectives, although some operations were shortened slightly because of schedule constraints. After riserless drilling and installation of casing to $703.9 \mathrm{~m}$ drilling depth below seafloor (DSF), riser operations included collection of cuttings (from $707.7 \mathrm{~m}$ mud depth below seafloor [MSF] to TD) and core (1509.7-1593.9 m core depth below seafloor $[\mathrm{CSF}]$ ) to document stratigraphy and sediment composition, measure rock physical properties, and identify structures. Because of limited coring op- 
erations and limitations associated with cuttings analyses (see "Insights from scientific riser operations"), we defined a single integrated set of lithologic units based on the range of data available from cuttings, wireline logging data, and cores (Fig. F5A, F5B). We ran LOT and MDT experiments that provide direct measurements of in situ stress magnitude, as well as formation pore pressure and permeability. During all phases of riser drilling, we also collected mud gas for geochemical analyses, from $703.9 \mathrm{~m} \mathrm{DSF}$ to TD (e.g., Wiersberg and Erzinger, 2007). A zerooffset, walkaway, and circular VSP experiment was conducted using a wireline array of seismometers within the borehole to define the seismic velocity and structure around the borehole and at the underlying plate boundary.

\section{Lithology}

Using the combination of data from wireline logs, cuttings, and limited core, we defined four distinct lithologic units composed of mud/mudstone with interbeds of sand, silt, and volcanic ash and tuff. The unit boundaries and lithologies are constrained by macroscopic description of cuttings and cores, smear slide and thin section observations, bulk X-ray diffraction (XRD) and X-ray fluorescence (XRF) analyses, and wireline logging data including gamma ray, caliper, density, photoelectric effect, spontaneous potential, resistivity (including resistivity images), and sonic velocity (Fig. F5A, F5B). Despite some chemical and physical artifacts in the cuttings and uncertainty in their depth of origin, lithologic boundaries defined by analysis of cuttings are generally consistent with boundaries defined by logging data:

- Unit I (modern-Pleistocene: 0 to younger than $\sim 0.9 \mathrm{Ma}$; 0-467 m LSF) is a silty mud with sandrich cycles that range from $\sim 10$ to $50 \mathrm{~m}$ in thickness.

- Unit II (Pleistocene: younger than $~ 0.9$ to $0.9 \mathrm{Ma}$; 467-791 m LSF; cuttings 707.7-812.7 m MSF) is silty mud with silt and sand interbeds and minor interbeds of volcanic ash.

- Unit III (Pleistocene-Pliocene: $\sim 0.9$ to $\sim 3.8 \mathrm{Ma}$; 791-1285 m WMSF; cuttings 812.7-1287.7 m MSF) is composed of silty mudstone, with rare silty sand interbeds. It is distinguished from Unit II by its overall finer grain size, higher wood/lignite content, slightly increased consolidation state, and higher organic content. On the basis of cuttings, we divided Unit III into two subunits, with Subunit IIIB distinguished from Subunit IIIA by increased wood/lignite and glauconite abundance.
- Unit IV (late Miocene: $~ 5.6$ to younger than $~ 7.9$ Ma; 1285 WMSF to TD; cuttings $1287.7-1603.7 \mathrm{~m}$ MSF) is a silty mudstone with minor silt interbeds and rare interbeds of fine vitric tuff. The Unit III/ IV boundary is marked by changes in several logging data sets, increased lithification, and several major compositional changes. It is also defined by a $\sim 1.8 \mathrm{Ma}$ age gap and an angular unconformity at its upper boundary that can be traced across the Kumano Basin (Fig. F6).

Overall, we interpret the stratigraphic succession as a series of forearc basin-filling mudstones with varying sand and silt turbidite abundance, underlain by older slope deposits and/or accretionary prism sediment. Unit I is sandier than other units drilled at Sites C0009 and C0002 (20 km seaward). Unit II is characterized by turbidites that are coarser than those in underlying Units III and IV and the units drilled at Site C0002 but markedly thinner and finer grained than those in Unit I above. Unit III includes two subunits (IIIA and IIIB) containing thinly bedded fine-grained turbidites deposited in the early $\mathrm{Ku}$ mano forearc basin. The lower subunit (IIIB) has an increased supply of terrigenous organic matter (i.e., wood fragments). The composition of detrital grains points to a source from exposed sedimentary and metasedimentary rock units (e.g., Taira et al., 1988; Isozaki and Itaya, 1990) and is consistent for Units I, II, and III.

Unit IV is mudstone containing thin-bedded finegrained turbidites. The presence of calcareous microfossil tests, although poorly preserved, suggests deposition above the late Miocene carbonate compensation depth (CCD) (see "Biostratigraphy"). It resembles Unit IV at Site C0002 in terms of sedimentary facies (Expedition 315 Scientists, 2009). Unit IV at Site C0009, however, is less deformed and we observed no clear sedimentary, geochemical, or structural evidence (see below) to conclusively indicate that this unit is composed of highly deformed frontally accreted trench sediment. Thus, Unit IV could be interpreted as either a weakly deformed package of accreted trench sediments, slope deposits, or sediments deposited in the distal reaches of the early $\mathrm{Ku}$ mano Basin.

\section{Structural geology and geomechanics}

At Site C0009, we documented geologic structures in cuttings from 1097.7 to $1512.7 \mathrm{~m} \mathrm{MSF}$, and in core from 1510.5 to $1593.9 \mathrm{~m}$ CSF. We also analyzed FMI borehole resistivity images from 710 to $1579.9 \mathrm{~m}$ WMSF. Although the FMI's limited coverage of the borehole wall and reduced data quality in the deeper borehole (Unit IV) precluded clear identification of 
borehole breakouts in resistivity images, we were able to use the FMI caliper to measure borehole enlargement associated with breakouts. We also documented drilling-induced tensile fractures (DITF) in some portions of the hole. Both of these data sets can be used to determine minimum and maximum horizontal stress orientation.

Vein structures identified in cuttings from the upper part of Unit IV are similar to those observed on previous drilling expeditions (e.g., Site C0002; Ashi et al., 2008) and in onshore exposures, and they are consistent with formation by dewatering or shakinginduced soft-sediment deformation. Faults identified in the cores exhibit two populations, one dipping at $10^{\circ}-30^{\circ}$ and the other at $50^{\circ}-70^{\circ}$, reflecting both thrust and normal faults. Although most faults do not exhibit a clear sense of offset, we observed some crosscutting relationships that indicate a complex deformation history in which faults exhibiting normal displacement both cut and are cut by faults having thrust displacement. We did not reorient structures identified in the cores because the cryogenic magnetometer was not on board during the expedition.

FMI images and caliper measurements provided additional structural data for Site C0009. In Subunit IIIA, beds dip gently north $10^{\circ}-15^{\circ}$, whereas in Subunit IIIB, they dip gently north-northwest. A $3 \mathrm{~m}$ thick zone of deformation and increased bedding dip is identified at the Subunit IIIA/IIIB boundary. Faults and fractures are also identified in Units III and IV and dip more steeply to the northwest than bedding planes, with a mean dip of $\sim 60^{\circ}$. Within Unit IV, caliper measurements from the FMI indicate that the hole is significantly enlarged, with one caliper commonly measuring $\geq 16-18$ inches in diameter and the other caliper typically close to 12 inches. The orientation of the largest caliper measurement (i.e., borehole enlargement) is stable even as the entire tool rotated in discrete $90^{\circ}$ clockwise increments while being pulled uphole. The mean value of that orientation, weighted for the depth of borehole sampled in each interval, defines an alignment $46^{\circ}-226^{\circ}$ (northeast-southwest). We interpret this orientation as a series of breakouts, representing the direction of the minimum horizontal stress $\left(S_{\mathrm{hmin}}\right)$. This indicates that the maximum stress in the horizontal plane $\left(S_{\mathrm{H} \max }\right)$ is oriented at $136^{\circ}-316^{\circ}$ (southeast-northwest), which is similar to the orientation of $S_{\mathrm{Hmax}}$ at IODP Sites C0001, C0004, and C0006 seaward of the megasplay fault but nearly perpendicular to that at Site C0002 located $20 \mathrm{~km}$ to the southeast at the seaward edge of the Kumano Basin (Kinoshita, Tobin, Ashi, Kimura, Lallemant, Screaton, Curewitz, Masago,
Moe, and the Expedition 314/315/316 Scientists, 2009) (Fig. F7).

\section{Biostratigraphy}

We established an age model for the drilled sequence at Site C0009 from calcareous nannofossil biostratigraphy, primarily utilizing cuttings samples (715.7$1603.7 \mathrm{~m} \mathrm{MSF}$ ) and supplemented with core catcher samples from 1509.7 to 1593.9 m CSF (Figs. F5A, F6). We analyzed 75 samples spaced at 5-30 m intervals, with closer spacing near key lithologic and zonal boundaries. Calcareous nannofossils are generally abundant throughout the section, and their preservation is moderate in the upper part of the hole but there is a trend toward poorer preservation downhole, especially below $\sim 1290$ m MSF within Unit IV. Except for a few samples from the top sand-rich interval in lithologic Unit II, most samples yielded abundant nannofossils and the majority of agediagnostic taxa appear reasonably continuous throughout their ranges. Therefore, most of the important Neogene and Quaternary datums (summarized by Raffi et al., 2006) were identified and hence the nannofossil zones of Martini (1971) recognized. However, frequent downhole contaminations prevented the use of some important nannofossil datums based on first (or first common) occurrence.

Our results indicate that the sampled sequence ranges in age from late Miocene ( $>7.1 \mathrm{Ma}$ but $<7.88$ Ma) to Pleistocene ( $>0.43 \mathrm{Ma}$ ). Unit II and the upper part of Subunit IIIA are early Pleistocene, and the rest of Unit III is Pliocene (Fig. F6A). Unit IV is late Miocene. We documented an unconformity spanning $\sim 1.8$ m.y. (5.6-3.8 Ma) between the late Pliocene (Subunit IIIB) and the late Miocene (Unit IV). The upper Miocene sequence continues to the base of the drilled section, with ages younger than 7.88 Ma.

\section{Geochemistry}

During riser drilling at Site C0009, we conducted scientific mud gas monitoring (e.g., Erzinger et al., 2006). The principal formation gas extracted from the returning drilling mud was methane, with up to $14 \mathrm{vol} \% \mathrm{CH}_{4}$ detected during initial drilling of the $12 \frac{1}{4}$ inch hole and up to 3 vol\% detected during hole opening to 17 inches. We also detected traces of ethane (up to 16 parts per million by volume [ppmv]) and propane (up to 3 ppmv). During drilling of the $12^{1 / 4}$ inch hole, methane concentrations were relatively low above $\sim 800 \mathrm{~m}$ MSF and were generally highest within Subunit IIIB from 1050 to $1220 \mathrm{~m}$ MSF. Below 1280 m MSF (approximately corresponding to the Unit III/IV boundary), methane concentrations decreased abruptly to $\sim 4-5$ vol\%. During 
hole opening to 17 inches, a better depth resolution was achieved by modifying the gas extraction setup; both the $12^{1 / 4}$ inch drilling and 17 inch hole-opening data sets exhibit similar downhole trends.

The distribution of methane correlates directly with the presence of wood and lignite in cuttings, implying that they are the primary source of hydrocarbons (Figs. F5A, F8). The molecular composition of hydrocarbons suggests a microbial source; the ratio $\mathrm{CH}_{4} /$ $\mathrm{C}_{2} \mathrm{H}_{6}$ was consistently $>500$ and typically $\sim 1000$, although this ratio might be somewhat biased by the lower solubility of methane in the drilling mud relative to ethane and propane. This interpretation is consistent with an estimated temperature of $\sim 48^{\circ} \mathrm{C}$ at the base of the borehole, which is too low for thermogenic hydrocarbon generation. Based on the correlation between stratigraphic observations and mud gas distribution, combined with the overall finegrained nature of the sediments in Unit III, gas migration through permeable strata seems unlikely to play a significant role in the observed gas distribution. This interpretation is also consistent with the absence of gases indicating a contribution from greater source depth (i.e., helium or heavy hydrocarbons). Taken together with data from physical property measurements (see "Physical properties"), we interpret these observations to indicate a moderate gas saturation $(\mathrm{Sw}=\sim 10 \%)$ that was probably generated in place.

The total organic carbon (TOC) content of cuttings samples ranges from 0.93 to $8.7 \mathrm{wt} \%$, with the highest values in Subunit IIIB between 1080 and $1240 \mathrm{~m}$ MSF. These values are consistent with the high abundance of wood/lignite observed in this unit and the occurrence of methane. TOC and total nitrogen (TN) exhibit a very similar depth distribution. The TOC/ TN ratio ranges from 13.8 to 74.5 with an average of 29.8; values are generally highest in Unit III and decrease in Unit IV. Marine organic matter typically exhibits TOC/TN ratios in the range of $\sim 4-10$, whereas the ratio for terrestrial organic matter is typically $>10$. This suggests that the source of organic matter in much of the borehole is terrestrial, which is also consistent with the wood and coal fragments observed in cuttings.

\section{Physical properties}

We obtained a wide range of physical property data from wireline logs and measurements on cores and cuttings (Fig. F5). These data include bulk density and porosity, $P$ - and $S$-wave velocity $\left(V_{\mathrm{P}}\right.$ and $V_{\mathrm{S}}$, respectively), magnetic susceptibility, electrical resistivity, and thermal conductivity (cores only). In general, bulk density gradually increases downsection and porosity (computed from bulk density and estimated from resistivity logs) decreases, which is consistent with a trend of increasing compaction with depth. $P$ - and $S$-wave velocities increase with depth overall, but the $P$-wave velocity profile is marked by excursions to lower values within Unit III.

Most physical property measurements exhibit changes at the major lithologic unit boundaries. For example, the slope of the compaction trend increases slightly across the Unit III/IV boundary at $1285 \mathrm{~m}$ WMSF; we interpret this to reflect a change in either lithology or compaction history (i.e., secondary consolidation associated with the increased age of the sediment in Unit IV or possible lateral compression). In addition to the change in the slope of the porosity-depth trend, we observe a decrease in measured density (and concomitant increase in computed porosity) at the Unit III/IV boundary. We suggest this is an artifact of the higher hydrous clay content in Unit IV relative to overlying units; postexpedition XRD analyses of the clay-sized fraction will address this by quantifying the abundance of smectite group clays.

On the basis of $P$-wave, $S$-wave, and resistivity logs, we identified four distinct zones of increased gas content in Unit III (Fig. F8). Specifically, we observe intervals characterized by low $V_{\mathrm{P}}$, low $V_{\mathrm{p}} / V_{\mathrm{S}}$ ratio (and thus low Poisson's ratio), and increased resistivity that correlate clearly with depths of increased methane documented by mud gas analyses (Fig. F8). A preliminary calculation suggests a gas saturation of $\sim 10 \%$.

We also observe a significant change in caliper response at the Unit III/IV boundary. Above this, the hole remains in gauge, whereas below the boundary we observe significant enlargement with one caliper measuring up to 16-18 inches (see "Structural geology and geomechanics"). This change in borehole conditions, taken together with the decrease in Stoneley wave velocity in this interval, may be related to increased deformation and/or fractured rock in Unit IV.

Moisture and density (MAD) density and porosity data from cores are in good agreement with the wireline logging data. In contrast, measurements conducted on cuttings appear to significantly overestimate porosity (by as much as $\sim 12 \%$ ) and underestimate bulk density. This discrepancy may be related to the small size of the cuttings that led to swelling during washing, exposure to drilling mud in the borehole, or water retention on the surfaces of small particles after washing. Although the absolute values of porosity measured on cuttings are most probably well in excess of true formation porosity, downhole trends may reflect real relative variations in formation bulk density and porosity. This and sev- 
eral other issues encountered in analysis of cuttings are discussed in more detail in "Insights from scientific riser operations."

\section{Downhole measurements}

\section{Stress, pore pressure, and permeability}

Measurement of in situ pore pressure and stress using the MDT wireline logging tool assembly was one of the new scientific operations for IODP conducted during Expedition 319. This wireline tool measures borehole pressure, formation pore pressure at the bed and meter scale, and least principal stress magnitude. We ran the MDT tool 12 times at Site C0009. This included nine single probe tests to measure in situ pore pressure and fluid mobility, and three dual packer tests in isolated intervals: one to measure formation permeability from a drawdown and recovery cycle, and two to measure in situ stress. Two of the single probe tests were conducted at the same depth stations as dual packer tests. The single probe test uses a circular probe sealed against the borehole wall to extract fluid and reduce formation pore pressure in a small volume and then records the subsequent pressure recovery. The dual packer test isolates an interval of the formation (configured for $1 \mathrm{~m}$ at Site C0009) to either draw down the pressure (again to estimate in situ pressure and permeability over a larger scale than the single probe test) or to increase the borehole pressure to create a hydraulic fracture and measure the least principal stress magnitude.

The nine in situ pore pressure measurements indicate that formation pore pressure is hydrostatic or elevated by only a few percent of the hydrostatic value to depths of at least $1463.7 \mathrm{~m}$ WMSF (the depth of the deepest reliable measurement) (Fig. F9A). The slight apparent overpressure could be due to pressurization of the formation by weighted drilling mud, an incorrect estimation of the hydrostatic pressure (e.g., if the integrated seawater density from mean sea level to the measurement point was slightly underestimated), or the presence of slight overpressure in the formation. The permeablities we measured with the single probe tests range from $\sim 10^{-16}$ to $10^{-14}$ $\mathrm{m}^{2}$ (Fig. F9B). Overall, the variation in permeability values is consistent with lithologic characteristics inferred from gamma ray logs; the higher permeabilities correspond to zones of lower gamma ray (i.e., sandier intervals). Analysis of the dual packer drawdown-recovery test at $1539.69 \mathrm{~m}$ WMSF in the clayrich and fine-grained Unit IV yielded a permeability value of $1.3 \times 10^{-17} \mathrm{~m}^{2}$. It is important to recognize that the MDT tool is generally designed for use in formations with permeabilities $>\sim 10^{-15} \mathrm{~m}^{2}$. In lowpermeability formations, both pore pressure and permeability estimates should be viewed with caution because the pressure recovery time may be considerably longer than the tool deployment time.

We conducted hydraulic fracturing tests near the top and bottom of the $12^{1 / 4}$ inch open-hole section at 874.30 and $1462.3 \mathrm{~m}$ WMSF using the MDT dual packer tool. The deeper test did not yield reliable results. For the shallower test, we observed a clear and repeatable instantaneous shut-in pressure of $34.8 \mathrm{MPa}$, which we interpret as the least principal stress $\left(\sigma_{3}\right)$ (Fig. F9A). This value is smaller than the vertical stress $\left(\sigma_{v}\right)$. If the principal stresses are horizontal and vertical, then this implies $\sigma_{3}=\sigma_{\text {hmin }}$; the measured value corresponds to an effective stress ratio $\left(\sigma_{\mathrm{hmin}}^{\prime} / \sigma_{\mathrm{v}}^{\prime}\right)$ of 0.82 . As part of standard riser drilling operations, we also conducted a LOT at the base of the 20 inch casing (708.6 m DSF). The leak-off pressures are $30.22-30.25 \mathrm{MPa}$ and, as was the case for the MDT hydraulic fracturing test, are less than $\sigma_{v}$, also indicating that $\sigma_{\text {hmin }}=\sigma_{3}$. However, the value of $\sigma_{3}$ obtained from this test is considerably lower than from the MDT test, with $\sigma_{\text {hmin }}^{\prime} / \sigma^{\prime}{ }_{v}=0.44$. Although there is considerable uncertainty in determining $\sigma_{3}$ from this type of test (e.g., Zoback, 2007), the LOT was repeatable and appears reliable.

\section{Vertical seismic profiling}

We conducted a walkaway VSP experiment in Hole C0009A using an array of 16 seismometers within the Versatile Seismic Imager wireline tool set inside the $13 \% 3$ inch casing between 2989 and $3217 \mathrm{~m}$ drilling depth below rig floor (DRF). The objective of the walkaway VSP experiment was to image the structure around the megasplay fault and décollement below the borehole and to evaluate seismic anisotropy of the basin sediment and accretionary prism around the borehole. The shooting vessel (Kairei) shot a single $53.4 \mathrm{~km}$ long transect in the dip direction of the subducting plate and a circular path of $3.5 \mathrm{~km}$ radius around the borehole. We obtained 880 shot records in the dip line and 275 shots in the circular line.

From the walkaway VSP records, we were able to identify direct wave arrivals, seismic phases associated with multiples in the water column, refractions from the accretionary prism, and reflections from interfaces below the borehole within the accretionary prism as well as from the splay fault and probably from the deeper décollement. The dense seismic array in the hole was effective enough that seismic waves traveling upward and downward were coherent and clearly distinguishable. We also observed subordinate seismic waves generated by the structure of the borehole that traveled along the casing at $\sim 6$ $\mathrm{km} / \mathrm{s}$. These phases were prominent in the vertical component at frequencies higher than $20 \mathrm{~Hz}$ and made it difficult to discern high-frequency phases 
from the formation. Therefore, deeper and weaker seismic phases appear clearer in horizontal component records because of smaller effects from such casing related phases.

Following the walkaway VSP experiment, we conducted a zero-offset VSP experiment using air guns deployed at $60 \mathrm{~m}$ offset from the borehole and obtained seismic data for the entire length of the borehole above $3217 \mathrm{~m}$ DRF by moving the seismic array upward from the depth of the walkaway VSP experiment in $\sim 121 \mathrm{~m}$ intervals. As was the case for the walkaway VSP, zero-offset VSP records also exhibited subordinate seismic phases traveling vertically in the casing. We also observed acoustic waves propagating inside the casing, which apparently reflected back at the bottom of the casing (at the casing shoe or float collar). In horizontal component records, there are clear phases propagating downward with apparent velocities in good agreement with velocities from wireline sonic logs and with the velocities from preexpedition processing of the 3 -D seismic reflection data. We picked these phases as $P$-waves propagating in the formation.

\section{Cuttings-Core-Log-Seismic integration}

We combined the zero-offset VSP (check shot) with wireline sonic velocities to derive a velocity-depth function at Site C0009 and used this velocity function to correlate the wireline, cuttings, and core data with time-based seismic data (Fig. F5). The velocities from the sonic log and check shot are lower than those used for 3-D seismic processing prior to the expedition. This is primarily due to a zone of low velocity and $V_{\mathrm{P}} / V_{\mathrm{S}}$ ratio from $\sim 1030$ to $1200 \mathrm{~m}$ WMSF in the wireline sonic data that corresponds to a zone of increased free gas in Unit III (Figs. F5A, F8).

We identified several prominent seismic surfaces that can be traced regionally within the Kumano Basin (seismic Surfaces S1 and S2 and Unconformities UC1 and UC2; Figs. F4, F6). The uppermost of these surfaces (S1) is a prominent reflector within Unit II at $\sim 600$ mbsf (Fig. F6A). Seismic Surface S2 is located at $750 \mathrm{~m} \mathrm{WMSF}, 40 \mathrm{~m}$ above the interpreted Unit II/III boundary (Figs. F5A, F6A). Unconformity UC1 is a prominent positive polarity reflector and marks an angular unconformity at the base of the low-velocity zone in Subunit IIIB (Figs. F5A, F6A), and we interpret that it is caused by the strong increase in impedance at the base of a gas-rich zone (Fig. F8). Gamma ray values are also slightly lower above Unconformity UC1 compared to below it, and we interpret this to record a lithologic change. Unconformity UC2 lies (approximately) at the Unit III/IV boundary and is marked by a decrease in density and an in- crease in velocity; the net result is a positive increase in impedance (Fig. F5A). Reflections within Unit III onlap Unconformity UC2 with an apparent northnorthwest to south-southwest direction.

Each lithologic unit is imaged as a distinct seismic facies. Lithologic Unit I is characterized by laterally continuous high-amplitude seismic reflections (Fig. F6A). These reflections are largely parallel; however, in the upper part of the section, they converge and onlap to the south-southeast (apparent direction in the plane of the seismic cross section shown in Fig. F6B) as Unit I thins. We interpret that the well-stratified and laterally continuous reflections are caused by abundant $10-50 \mathrm{~m}$ thick sand cycles, as recorded in gamma ray data that were deposited in deep water as turbidite deposits. Unit II is characterized by lower frequency reflections and slightly reduced amplitude relative to Unit I (Fig. F6A). The reflectors are generally not continuous; many intersect each other when traced laterally. The low amplitude in Unit II is broadly consistent with an interpretation of silty clay with few silt or sand interbeds. There are several bright reflections within Subunit IIIA, but the unit is generally less reflective than overlying units (Fig. F6A). The upper part of Subunit IIIB is relatively transparent and corresponds to a zone with uniformly low velocity abundant wood fragments identified in cuttings and elevated mud gas methane concentrations.

\section{Site C0010}

Operations at Site C0010 included drilling with LWD/MWD across the megasplay fault to a TD of $555 \mathrm{~m}$ LSF, casing the borehole with casing screens at the fault, conducting an observatory dummy run to test strainmeter and seismometer deployment procedures, and installing a simple pore pressure and temperature monitoring system (smart plug). Although the smart plug is relatively simple, it marks the first observatory placement in NanTroSEIZE. All of the planned science objectives for Site C0010 were achieved, although casing operations were adjusted to fit hole conditions after drilling to TD $(560 \mathrm{~m}$ DSF) with $95 / 8$ inch casing installed to $500 \mathrm{~m}$ DSF instead of the planned 525 mbsf outlined in the prospectus. LWD/MWD data (gamma ray and resistivity, including resistivity at bit images) were collected, allowing (1) definition of major lithologic unit boundaries and of the shallow megasplay fault zone and (2) identification of the fault zone for placement of the screened casing joints. Through comparison with previously drilled Site C0004 (Kinoshita, Tobin, Ashi, Kimura, Lallemant, Screaton, Curewitz, Masago, Moe, and the Expedition 314/315/316 Sci- 
entists, 2009) these data also provide insights into along-strike differences in the architecture of the megasplay fault and its hanging wall.

After drilling the hole and in preparation for a future permanent observatory installation, a dummy sensor run was carried out to evaluate reentry operations during instrument deployment. After casing was completed and the borehole cemented, two dummy run tests were conducted, including adjustments for the effects of the Kuroshio Current, which reached speeds of $4.5 \mathrm{kt}$ during the experiment. After the dummy run reentry simulations were completed, the smart plug was installed to monitor temperature and pore pressure within the megasplay fault zone, with retrieval anticipated for 2010-2011.

\section{Lithology}

We defined three logging units at Site C0010 on the basis of LWD/MWD measurements (gamma ray and bit resistivity) (Fig. F10) and guided by previous results at nearby Site C0004 (Expedition 314 Scientists, 2009; Expedition 316 Scientists, 2009) (Fig. F11). Although in detail the sites are not identical (e.g., see "Log-Seismic integration"), the observations at Site C0004 provide valuable constraints on lithologic variations at Site C0010 (Kinoshita et al., 2008; Kimura et al., 2008). In particular, data from previous drilling at Site C0004 show that lithologic changes are best defined based on gamma ray measurements.

We define three distinct lithologic packages at Site C0010. From top to bottom, these are slope deposits (Unit I, 0-182.5 m LSF), thrust wedge (Unit II, 182.5$407 \mathrm{~m} \mathrm{LSF}$ ), and overridden slope deposits (Unit III, $407 \mathrm{~m} \mathrm{LSF}$ to TD). Unit I is divided into two subunits. Subunit IA (0-161.5 m LSF) is characterized by gamma ray and bit resistivity patterns similar to logging Unit I at Site C0004 (Figs. F10, F11) and we interpret it as hemipelagic slope sediments composed primarily of mud with minor distal turbidite interbeds. We interpret Subunit IB (161.5-182.8 m LSF) as slope sediments composed of material reworked from the underlying thrust wedge.

Unit II (182.5-407 m LSF) is a thrust wedge comprising the hanging wall of the megasplay fault and is correlated with logging Unit II (Expedition 314 Scientists, 2009) and lithologic Units II and III (Expedition 316 Scientists, 2009) at Site C0004. The thrust wedge at Site C0010 has higher gamma ray than at Site C0004, which may indicate higher clay content (Fig. F11). Unit III (407 m LSF to TD) is composed of slope sediments overridden by the thrust wedge and correlates with logging Unit III and lithologic Unit IV at Site C0004. On the basis of the LWD data and coring results from Site C0004, we interpret Unit III as hemipelagic muds with minor turbidite interbeds and rare volcanic ash layers.

\section{Structural geology and geomechanics}

We measured the attitudes of faults, bedding, and breakouts from LWD resistivity image data. As a result of ship heave during logging operations, the resistivity image data exhibit variable quality. In most of the bedding data, we identified eastward dips of $\sim 45^{\circ}-60^{\circ}$. However, there is considerable scatter in both dip magnitudes and bedding orientations, and because of limited data quality there are a limited number of observations $(N=11)$. Faults dip to the west and south, with most dips ranging from $\sim 40^{\circ}$ to $80^{\circ}$. We observe the highest concentration of faults near the base of the thrust wedge. Notably, the two logging runs through the lowermost $\sim 60 \mathrm{~m}$ of the thrust wedge (2900-2970 m LRF) are markedly different. The first logging run (Run 1 during drilling) exhibits faults with a wide range of dips, generally to the south and west. The second run, which was conducted after reaming in an open hole (Run 2), exhibits steeply dipping faults $\left(>45^{\circ}\right.$ and mostly $\left.>60^{\circ}\right)$, and the shallowly dipping faults noted in the first logging run are not observed.

Borehole breakouts show that $S_{\mathrm{H} \max }$ trends northwest-southeast, similar to other sites on the outer slope along the NanTroSEIZE transect (Sites C0001, C0004, and C0006) (Kinoshita et al., 2008; Tobin et al., 2009) (Fig. F7). A sharp discontinuity in stress orientation occurs across the base of the thrust wedge and is consistent with a fault discontinuity (Barton and Zoback, 1994). The enlargement of breakouts during the interval between the two logging runs indicates that the breakouts grew with time in this environment, in contrast to observations from more lithified rocks (Zoback, 2007).

\section{Physical properties}

Physical properties from logging data collected at Site C0010 include gamma ray, bit resistivity, shallow-, medium-, and deep-button resistivity, and ring resistivity (Fig. F10). In addition, we estimated porosity from resistivity. However, this approach is limited by the fact that there are no data from cores, cuttings, or logging to calibrate the transform from resistivity to porosity (e.g., Kinoshita et al., 2008; Conin et al., 2008).

Ring resistivity exhibits an overall increase downhole, ranging from 0.7 to $0.9 \Omega \mathrm{m}$ in the slope sediments of Unit I (0-182.5 m LSF). Resistivity in the overridden slope deposits of Unit III (407-554 m LSF) below the thrust wedge (Unit II) follows the same trend, with values between 0.8 and $1.2 \Omega \mathrm{m}$. Re- 
sistivity values in both Units I and III are similar to those for slope deposits at Site C0004 (Fig. F11). The thrust wedge (Unit II) is characterized by significantly higher overall resistivity than the slope deposits above and below. In the lower portion of Unit II (260-407 m LSF) we observe considerable scatter in resistivity, with fluctuations from 1.5 to $2.5 \Omega \mathrm{m}$ over distances of $\sim 10-20 \mathrm{~m}$.

The overall higher resistivity and the fluctuations in resistivity in the thrust wedge correlate with increased overall gamma ray values and excursions to lower gamma ray values, respectively (Figs. F10, F11). The overall higher resistivity values may reflect increased compaction within the thrust wedge relative to the overlying and underlying slope sediments, increased clay content leading to increased tortuosity, or a combination of the two. We interpret that the large fluctuations superimposed on the overall trend reflect either interbedded coarser grained zones or more intensely faulted and fractured intervals.

We estimated porosity from resistivity using parameters for Archie's law derived at nearby Sites C0001 and $\mathrm{C0004}$ that also penetrated slope sediments and the underlying wedge (Kinoshita et al., 2008; Kimura et al., 2008; Conin et al., 2008), where both logging and core data were available. For the slope apron (Unit I) and underthrust (Unit III) sediments at Site C0010, an exponential porosity-depth trend (Athy, 1930) fits the computed porosities well. In contrast, the estimated porosity of the thrust wedge is markedly lower because of its considerably higher resistivity, although, as noted above, the higher resistivity may be partly due to increased clay content. Preliminary calculations suggest that lithologic effects are unlikely to fully explain the magnitude of resistivity increase within the thrust wedge, indicating that it probably reflects increased compaction related to its burial history or higher in situ mean stress in the thrust wedge relative to the slope sediments.

\section{Log-Seismic integration}

We used the time-depth data acquired at Site C0004 (Expedition 314 Scientists, 2009) to correlate the logs to the seismic data at Site C0010. The Unit I/II boundary marking the top of the thrust wedge is imaged with a weak positive polarity seismic reflection that is coincident with a sharp increase in resistivity (Figs. F10, F11). The Unit II/III boundary between the base of the thrust wedge and overridden slope sediment is recorded by a prominent negative polarity reflection. At this boundary, the resistivity drops markedly. We infer that velocity and density also de- crease at this boundary, resulting in a negative impedance contrast.

At Site C0010, gamma ray values in the thrust wedge increase gradually from 65 gAPI at the top to 120 gAPI at the thrust wedge center and decrease to 80 gAPI at the base (Fig. F10). Several fluctuations in gamma ray values with depth are superimposed on this overall trend, with values ranging from 60 to 80 gAPI units; resistivity cycles within the thrust wedge coincide with decreases in gamma ray values. We also observe greater seismic reflection amplitudes within the thrust wedge at Site C0010 than at Site C0004 (Fig. F11; cf. Fig. F4B). We conclude that the fluctuations in composition or physical properties within the thrust wedge at Site C0010 recorded in gamma ray and resistivity drive differences in velocity and density (impedance) that generate these seismic reflections (see "Lithology" and "Physical properties"). These results suggest significant variation in composition and/or physical properties of the thrust wedge along strike over a scale of only a few kilometers. A striking feature of seismic profiles across the thrust wedge is that the negative polarity reflector is weak at the tip of the thrust wedge and its amplitude increases downdip (Fig. F4B). This most likely reflects increasing consolidation in the thrust wedge relative to the underlying material.

\section{Observatory}

\section{Sensor dummy run test}

As part of our operations at Site C0010, we conducted two sensor dummy run tests to simulate future installation of long-term observatory instruments, with the goal of documenting vibration and shock associated with running the instrument package through the water column and reentering the borehole. During the first dummy run, two seismometers, an accelerometer-tiltmeter, a strainmeter, and nine miniature temperature loggers (MTLs) were attached to the sensor tree (Fig. F12A, F12B). In addition, two full joints and one pup joint of tubing were attached below the strainmeter to replicate the planned future installation procedure. Because of the high current in the vicinity of Site C0010 ( 4-5 kt surface current), we ran the instrument carrier to $\sim 1689 \mathrm{~m}$ DRF in a low-current area and then drifted toward the drill site. Unfortunately, while drifting to the site for reentry, one seismometer was dropped from the instrument carrier, and the strainmeter was detached from the bottom of the carrier because of strong current-induced vortex-induced vibration (VIV) on the drill pipe. After visual confirmation that these components were lost (by ROV at 1650 meters below sea level [mbsl]), we retrieved the instru- 
ment carrier without reaching the seabed. However, acceleration, tilt, and temperature data in the water column were collected during this dummy run.

After the first run, we repaired the instrument carrier and conducted a second dummy run using the accelerometer-tiltmeter attached to the instrument carrier to evaluate shock, acceleration, and vibration during reentry. This run also included a dummy strainmeter, with similar dimensions and mass to a real strainmeter, and two full joints of $3 \frac{1}{2} 2$ inch tubing attached below the instrument carrier. The bottom of the sensor tree was reentered into the wellhead three times. The reentry operations were generally very smooth; during the second and third reentry, the tubing below the sensor tree hit the reentry cone. After the sensor tree was recovered, the accelerometertiltmeter was checked. Unfortunately, recording stopped because of damage sustained by vibration in the water column, and no acceleration and tilt data were obtained for the reentry test.

\section{Smart plug installation}

After the observatory dummy runs were completed, we suspended Hole C0010A by installing a smart plug instrument package below a mechanically set retrievable casing packer (Fig. F12C, F12D). The retrievable packer was set inside casing above two screened casing joints; the smart plug and screen placement in the casing were configured to continuously monitor pore pressure and temperature in an isolated interval of formation including the splay fault, and to monitor hydrostatic pressure as a reference (Fig. F12C). The smart plug contains two highprecision pressure transducers with period counters and four temperature sensors (one as part of each pressure gauge for compensation, one platinum chip thermistor, and one stand-alone MTL) in a shockproof housing (Fig. F12D). The self-contained instrument has a recording lifetime of $\sim 7 \mathrm{y}$.

The smart plug is designed to thread onto the casing packer. Based on the difficulties encountered during the dummy run, we further secured the smart plug to the crossover below the packer by tack-welding prior to running it into the water column (Fig. F12D). The smart plug safely entered the hole and the packer was set at $365 \mathrm{~m}$ DSF. Retrieval of the bridge plug and instrument package is anticipated for 2010 or 2011 when a more sophisticated longterm monitoring system will be deployed at Site C0010 (Fig. F13).

\section{Key results and implications}

\section{Geomechanics: structures and stress state}

We collected several data sets at Sites C0009 and C0010 that provide constraints on present-day in situ stress orientation and magnitude, as well as on past deformation. At Site C0009, borehole breakouts inferred from wireline calipers in Unit IV (1285$1580 \mathrm{~m}$ WMSF) indicate that $S_{\mathrm{H} \max }$ is oriented $136^{\circ}-$ $316^{\circ}$ (northwest-southeast). DITF tentatively interpreted from borehole resistivity images in Unit II ( 800-1000 m WMSF) are also compatible with a northwest-southeast oriented $S_{\mathrm{Hmax}}$. This orientation is $\sim 90^{\circ}$ to that at Site C0002, located $\sim 20 \mathrm{~km}$ seaward in the Kumano Basin (Fig. F7). At Site C0010, breakouts observed in RAB images indicate a $S_{\mathrm{H} \max }$ orientation of $145^{\circ}-325^{\circ}$ (northwest-southeast), consistent with that seen at previously drilled Sites C0001, C0004, and C0006 on the outer continental slope between the seaward edge of the Kumano Basin and the subduction trench (Tobin et al., 2009). The emerging picture of stress conditions (see also Kinoshita et al., 2008; Tobin et al., 2009) across the margin from borehole observations and fault patterns observed in seismic reflection data is one in which $S_{H_{\max }}$ is slightly oblique to the plate convergence direction (but approximately perpendicular to the trench) in the outer accretionary wedge (Fig. F7). Near the seaward portion of the Kumano Basin, there is active northwest-southeast extension approximately perpendicular to the trench but limited to an $\sim 15-20 \mathrm{~km}$ wide zone. Landward of this, $S_{\mathrm{H} \max }$ rotates back to an orientation nearly perpendicular to the trench and similar to that on the outer slope.

We also obtained two independent direct measurements of $\sigma_{3}$ magnitude at Site C0009 from an MDT hydraulic fracturing test at $879 \mathrm{~m}$ WMSF and a LOT at $704 \mathrm{~m}$ DSF (Fig. F9). In both cases, $\sigma_{v}$ is greater than the measured value of $\sigma_{3}$. Under the assumption that the principal stresses are horizontal and vertical, we conclude that $\sigma_{3}$ is horizontal $\left(\sigma_{\mathrm{hmin}}=\sigma_{3}\right)$ and the vertical stress is either the maximum or intermediate principal stress $\left(\sigma_{v}=\sigma_{1}\right.$ or $\left.\sigma_{2}\right)$. Taken together, the results from resistivity imaging (breakouts and DITF) and direct stress measurement (MDT and LOT) at Site C0009 indicate either a normal or strike-slip faulting regime in which $S_{\mathrm{H} \max }$ is oriented northwest-southeast at Site C0009. In the case of normal faults, the dominant fault strike would be northwest-southeast. The effective stress ratio $\left(\sigma^{\prime}{ }_{\text {hmin }} /\right.$ $\sigma_{v}^{\prime}$, where effective stress is given by the total stress 
minus the pore fluid pressure, assumed to be hydrostatic) is significantly greater for the MDT measurement $\left(\sigma^{\prime}{ }_{\mathrm{hmin}} / \sigma_{\mathrm{v}}^{\prime}=0.82\right)$ than for the LOT $\left(\sigma_{\mathrm{hmin}}^{\prime} / \sigma_{\mathrm{v}}^{\prime}=\right.$ 0.44) (Fig. F9A). We consider the MDT measurement to be slightly more reliable (see "Downhole measurements"). The effective stress ratio obtained in the LOT is consistent with active normal faulting for a friction coefficient of $\mu=\sim 0.4$, whereas the differential stress obtained from the MDT measurement is considerably smaller and insufficient to drive active normal faulting unless $\mu<\sim 0.15$ (e.g., Zoback, 2007).

In addition to in situ stress indicators, we documented fault types and orientations from resistivity images, seismic reflection data, and cores at Site C0009 to gain insight into deformation history and the associated stress conditions when the structures were active. The relative timing of different phases of faulting can be determined in some cases, but recent fault activity cannot be confirmed except where faults cut the seafloor in seismic reflection data. However, it is important to note that these still may not reflect present-day (instantaneous) stress conditions. Fractures in resistivity images, including one documented normal fault, strike northeast-southwest, and most dip to the northwest (average dip = $45^{\circ}$; modal dip $=60^{\circ}-70^{\circ}$ ). Cores exhibit a range of fault types, crosscutting relationships, and orientations. In seismic reflection data close to Site C0002, recently active normal faults striking northeastsouthwest and a second, less prevalent set striking northwest-southeast are observed (Kinoshita, Tobin, Ashi, Kimura, Lallemant, Screaton, Curewitz, Masago, Moe, and the Expedition 314/315/316 Scientists, 2009). In the landward part of the Kumano Basin near Site C0009, normal faults are sparse overall, and the northwest-southeast striking set is slightly more common relative to the northeastsouthwest striking set. The presence and orientation of normal faults in the seismic reflection data (northwest-southeast strike most common) are generally consistent with in situ stress magnitude and orientation data. However, the predominant northeastsouthwest strike of faults and fractures documented in borehole FMI images at Site C0009 is not; if they are normal faults, they are inconsistent with the orientation of $S_{\mathrm{Hmax}}$, whereas if they are thrusts they are inconsistent with the fact that $\sigma_{\mathrm{hmin}}<\sigma_{\mathrm{v}}$.

There are several potential explanations for this range of observations. One possibility is that the structures identified in FMI images are not active and therefore should not be compared with the presentday stress regime at Site C0009. This hypothesis is consistent with the fact that the faults and fractures measured by FMI data are resistive, suggesting that they may not be currently active (e.g., Barton et al.,
1995). The discrepancy between past and in situ stress states could be related to variations in stress during the earthquake cycle or to longer term processes related to the migration of deformation patterns within the basin. At Site C0002, however, fault orientations and present-day stress indicators are in agreement and indicate northwest-southeast extension normal to the margin (Tobin et al., 2009). This state of stress could have existed at Site C0009 previously and could explain the fault orientations in FMI data.

Alternatively, it is possible that measurements of stress state and those of long-term strain taken at different depths in the borehole represent changes in the stress regime with depth. In this case, the stress regime would be consistent with normal faulting in the upper $\sim 900-1200$ mbsf and transition to one of lateral compression below this, perhaps across the boundary into Unit IV. A third possibility is that the two horizontal principal stresses are close in magnitude in the landward portion of the basin (i.e., near Site C0009), such that $\sigma_{\mathrm{hmin}} \approx \sigma_{\mathrm{H} \max }<\sigma_{\mathrm{v}}$ (i.e., $\sigma_{3} \approx \sigma_{2}<$ $\sigma_{1}$ ). This stress state would permit normal faulting on structures as observed in seismic reflection data and borehole FMI images, while honoring the MDT and LOT stress measurements indicating $\sigma_{\mathrm{hmin}}<\sigma_{\mathrm{v}}$. However, the latter hypothesis does not explain the observation of only one dominant (northeast-southwest) strike for structures in the FMI resistivity data.

\section{Forearc basin development and correlation with Site C0002: depositional and tectonic environment}

Our interpretation of new data from Site C0009, evaluated in the context of previous results from drilling in the Kumano Basin (Ashi et al., 2008; Kinoshita et al., 2008), parallels the interpretation of geological and tectonic evolution initiated by the Expedition 314 and 315 scientists from drilling data at Site C0002 (Expedition 314 Scientists, 2009; Expedition 315 Scientists, 2009). At both Sites C0009 and C0002, drilling penetrated through Pliocene-Quaternary aged basin fill and across a basin-wide unconformity identified in seismic reflection data into finer grained, tilted, and variably deformed late Miocene sediments below. Four lithologic units were described at both drill sites. These units (Units I and II taken together, Unit III, and Unit IV) comprise three depositional sequences (Fig. F6).

At both sites, the lowest stratigraphic unit (Unit IV) is composed of mudstone with thin-bedded finegrained turbidites. At Site C0002, sediments of this lower unit are significantly deformed and have undergone moderate carbonate dissolution, interpreted 
as deposition below or near the CCD. This unit was interpreted as accretionary prism material by Expedition 314 and Expedition 315 scientists (Ashi et al., 2008; Tobin et al., 2009). At Site C0009, Unit IV is weakly deformed and shows the presence of carbonate, indicating deposition above the CCD. From the data collected at Site C0009 and comparison with previous drilling results at Site C0002, we interpret Unit IV as weakly deformed accreted trench sediments, as trench-slope deposits overlying accreted trench sediments, or as sediments deposited within the earliest Kumano forearc basin. Above Unit IV, Unconformity UC2 exhibits more than $1000 \mathrm{~m}$ of relief between Sites C0009 and C0002 and marks a hiatus of approximately equal age and duration at both sites ( 5.6-3.8 Ma) (Fig. F6). This suggests a tectonic event of regional significance, possibly related to the onset of out-of-sequence thrusting in the prism or to basement ridge subduction or underplating.

The lower part of Unit III at Site C0009 is approximately coeval with Unit III at Site C0002 but is considerably thicker at Site C0009; this part of the forearc basin sequence is highly variable in thickness throughout the basin (Fig. F6B). At Site C0002, 20 $\mathrm{km}$ farther seaward in the basin, it is interpreted as a condensed section of early forearc basin or slope basin/apron mudstones (Ashi et al., 2008). At Site C0009, this unit is distinguished from its lateral equivalent at Site C0002 by the presence of silt and ash beds and by abundant terrigenous input including wood and lignite (Figs. F5A, F8). We suggest that Unit III at Site C0009 represents early (unconformable) forearc basin or slope deposits, some of which may be associated with transport from out of the plane of the cross section shown in Figure F6B and F6C.

Seismic Surface S2 separates laterally continuous high-amplitude reflections above from a more acoustically transparent unit of variable thickness below and is interpreted as a time transgressive surface based on biostratigraphic constraints at both Sites C0002 and C0009 (Fig. F6B, F6C). Seismic Reflectors S-A and S-B downlap onto this surface near Site C0009 (Fig. F6B, F6C). Units I and II are a conformable package of sediments grading upward from mud (Unit II) to interbedded mud and sand (Unit I). This conformable succession was deposited at both Sites $\mathrm{C} 0009$ and C0002. However, it is greatly expanded at Site C0009, with sedimentation rates of $~ 700-800$ $\mathrm{m} / \mathrm{m} . \mathrm{y}$. We suggest that these strata record infilling of the Kumano Basin and the progressive landward (northwestward) migration of the depocenter, likely caused by underplating and/or slip on the megasplay with resulting uplift of the seaward edge of the basin (e.g., Moore et al., 2007).

\section{Plate boundary structure from walkaway VSP experiment}

A collaborative effort between IODP-Center for Deep Earth Exploration and JAMSTEC enabled a long-offset two-ship walkaway VSP experiment using an air gun source towed by the Kairei, along with a zerooffset VSP using a source at the drillship, in both cases shooting to receivers within the borehole. The walkaway VSP tracklines included a single line crossing over the location of the borehole with offsets up to $30 \mathrm{~km}$ and a circular trackline around the borehole with $\sim 3.5 \mathrm{~km}$ radius to investigate anisotropy. The long offsets allowed refractions and reflections from the accretionary wedge, plate boundary, and subducting plate to be recorded at the wireline tool within the borehole to 1200 mbsf. Recording arrivals in the borehole environment provides a higher resolution image than surface ship acquisition or OBS because the seismometers are coupled to the stiff and less attenuative formation; this configuration also allows high-fidelity measurement of shear waves converted from $P$-waves at subsurface boundaries. The data will allow seismic analyses of the velocity structure of the subduction zone forearc and the seismic attributes of the plate boundary in the region beneath the borehole at $\sim 10-12 \mathrm{~km}$.

\section{Architecture and along-strike variation of the megasplay fault}

Although we drilled Site C0010 with only a limited suite of LWD/MWD tools, the resistivity and gamma ray data sets provide a useful basis for comparison with nearby Site C0004, located $\sim 3.5 \mathrm{~km}$ along strike to the northeast. Based on the two penetrations of the thrust wedge, along with observations from 3-D seismic reflection data, it is clear that the character and physical properties of the megasplay fault system vary markedly along strike (Fig. F11).

At Site C0010, both gamma ray values and resistivity are higher in the thrust wedge than in the slope sediment above and below (Figs. F10, F11). In contrast, at Site $\mathrm{C0004}$ gamma ray values and resistivity within the thrust wedge are only very slightly higher than in the overlying and underlying units and are considerably lower than in the thrust wedge at Site C0010 (Kinoshita et al., 2008). Both gamma ray and resistivity logs are also characterized by fluctuations to lower values in the thrust wedge at Site C0010 that are not observed at Site C0004. The values for the minima in gamma ray and resistivity at Site C0010 are similar to those for the entire thrust wedge at Site C0004.

The base of the thrust wedge at Site C0010 is marked by a negative polarity seismic reflection. In contrast, 
the base of the thrust wedge at Site C0004 is marked by a positive polarity reflection, consistent with an increase in impedance as expected from observed $P$ wave velocity and bulk density from LWD and core data at this site (Kinoshita et al., 2008; Kimura et al., 2008). The thrust wedge in the vicinity of Site C0004 is seismically transparent in character, whereas at Site C0010 there are several clear reflectors, which likely correlate with the observed variations in gamma ray and resistivity (Fig. F11). From both LWD azimuthal resistivity images and seismic data, the base of the thrust wedge is sharper at Site C0010 than at Site C0004, where coring of the latter documented a $\sim 50 \mathrm{~m}$ thick fault zone (or "fault-bounded package") (Kimura et al., 2008). This is consistent with the observation that at Site C0010 the mean borehole breakout orientation changes abruptly by $\sim 20^{\circ}-30^{\circ}$ across the base of the thrust wedge, whereas at Site C0004 it changes gradually (Kinoshita, Tobin, Ashi, Kimura, Lallemant, Screaton, Curewitz, Masago, Moe, and the Expedition 314/315/316 Scientists, 2009).

We suggest that the overall higher values of gamma ray and resistivity reflect increased compaction in the thrust wedge at Site C0010 relative to the sediment above and below and relative to the thrust wedge at Site C0004, although it is also possible that these data could reflect a higher clay content. In the latter case, resistivity would be higher due to increased tortuosity associated with fine grain size and surface area. Similarly, the fluctuations in gamma ray and resistivity in the thrust wedge at Site C0004 could reflect variations in porosity or fracture density (with lower values associated with zones of increased fracturing or lower porosity), compositional layering, or a combination of the two.

The negative polarity reflection at the base of the thrust wedge at Site C0010 also suggests that it has a lower porosity than the overridden slope sediments below. However, based on the compaction trend for the slope sediments above and below the thrust wedge inferred from resistivity data (Conin et al., 2008), the overridden slope sediments do not appear to be underconsolidated, as might be the case for compaction disequilibrium (Hart et al., 1995; Saffer, 2003). Thus we conclude that the thrust wedge at Site C0010 is overcompacted, meaning that its porosity is anomalously low for its burial depth. This could result from increased mean effective stresses in the thrust wedge or from uplift of the wedge along the megasplay from greater depth.

At Site C0004, the thrust wedge exhibits porosity similar to the slope sediments and there is no evidence for enhanced compaction. Downdip from Site C0004, the seismic reflection polarity at the base of the thrust wedge becomes negative, most likely indicating increased compaction of the thrust wedge. Overall, we suggest that in the area of Site C0010 the thrust wedge comprises a consolidated and fractured package that probably originated at greater depth than the thrust wedge sampled at Site C0004. In contrast, the thrust wedge at Site C0004 may primarily be composed of reworked and deformed slope deposits. This interpretation is consistent with the location of Site C0010 on the flank of a lateral ramp on the megasplay fault (Fig. F11).

\section{Insights from scientific riser operations}

Expedition 319 marked the first riser drilling in IODP history. As noted above, this allowed us to conduct several scientific operations for the first time in IODP, including measurement of in situ stress, permeability, and pore pressure using the MDT tool, real-time analysis of mud gases, and analysis of cuttings for sedimentological, biostratigraphic, chemical, structural, and physical property data. Here, we briefly discuss some of the key insights gained from each of these new endeavors.

\section{Stress, permeability, and pore pressure from MDT and LOT measurements}

During Expedition 319, we deployed the MDT wireline logging tool in riser Hole C0009A to measure in situ formation pore pressure, formation permeability (often reported as mobility = permeability/viscosity), and in situ stress magnitude at several isolated depth intervals. This was the first time that the tool had been used in IODP drilling because it is currently not usable with the small-diameter riserless drill pipe used by IODP. We conducted nine single probe tests to measure formation pore pressure and fluid mobility and three dual packer tests (one drawdown test to measure formation hydraulic properties and two hydraulic fracturing tests to measure the least principal stress magnitude) (cf. Fig. F9). Successful deployment of this tool to measure in situ pore fluid pressure and stress magnitude deeper within the accretionary prism and in the vicinity of major fault zones in future riser holes will constitute a major breakthrough in understanding subduction zone fault mechanics and is a critical part of the NanTroSEIZE program. However, there are limitations in using the MDT tool successfully that warrant consideration, most notably that pore pressure and permeability measurements may be unreliable in low-permeability formations $\left(k<\sim 10^{-15} \mathrm{~m}^{2}\right)$ because the time required for pressure equilibration can greatly exceed the poten- 
tial deployment time. Expedition 319 operations and results also highlight the value of obtaining FMI or other borehole imaging data prior to running the MDT in order to select measurement targets that will yield meaningful data.

\section{Sampling and analysis of cuttings and mud gas}

We collected samples from the riser drilling mud, including cuttings, mud, and mud gas, during riser drilling at Site C0009. The results of shipboard analyses will provide guidance for future IODP riser drilling by serving as a blueprint for handling, treatment, and analysis approaches and by demonstrating the types and quality of data that can be obtained from these materials, especially for poorly lithified shallow sediments and sedimentary rocks. In addition to basic lithological description and microfossil analysis to define ages, for sufficiently lithified cuttings (deeper than $1000 \mathrm{~m}$ MSF in $\sim 2.5 \mathrm{Ma}$ claystones at Site C0009) we were able to document deformation features preserved in cuttings, measure physical properties including porosity and density, and measure composition by XRD, XRF, and carbonate analyses. We also conducted several experiments on cuttings and core samples to investigate the sensitivity of shipboard measurements to cuttings processing techniques (including the composition of fluid used for washing and the soaking time), to the cuttings size fraction(s) used for measurements, and to different drilling modes and mud compositions.

One concern in using drilling mud and cuttings for scientific analysis centered on the ability to obtain intact cuttings from shallow ( $<2000 \mathrm{~m}$ MSF) sediments and sedimentary rock and on uncertainty about the material's depth of origin. Comparisons between cuttings (collected from $5 \mathrm{~m}$ depth intervals) and wireline log data at Site C0009 indicate a likely depth uncertainty of $\sim 10 \mathrm{~m}$, but mixing during mud ascent and/or cavings from uphole may occur over larger distances. A second concern was that cuttings may be preferentially preserved from particular lithofacies (i.e., more lithified or cohesive claystones) and thus provide a biased sampling of the formation. Initial results suggest that this is likely the case. We conclude that sedimentological and geochemical data from cuttings (at least over the depth range we encountered) are useful for some applications, including the definition of overall lithofacies from relative abundance of lithic fragments, mudstone cuttings, and disaggregated sands, or the characterization of mudrock chemistry, provenance, and compositional variations. Data from cuttings may be less meaningful for other applications such as quan- titative grain size assessment, detailed lithofacies characterization, chemical analyses if there are effects from interaction with drilling mud, and physical property measurements. This emphasizes the importance of collecting complementary data sets (e.g., spot cores for calibration and log data) to supplement cuttings analysis.

Based on comparison between cuttings, cores, and logs, we also noted that the absolute values for some measurements on cuttings samples do not accurately reflect formation properties, although trends in these data sets show good agreement with equivalent log or core data in some cases. This is particularly true for physical properties and some geochemical analyses. For example, the high $\mathrm{pH}$ of the drilling mud likely affects carbonate, calcium, and carbon content values and as a result also generates errors in relative abundance of mineral phases defined by bulk XRD. However, variation in carbonate content downhole does not correlate with mud $\mathrm{pH}$ variation. This chemical contamination correlates with the time the cuttings were exposed to drilling mud in the borehole. Similarly, porosity values from cuttings are anomalously high, both with respect to their depth of origin and in comparison to log and core data; the discrepancy varies with sample handling and washing procedures and with soaking time. Thus it appears that the absolute values of compositional and physical property data from cuttings are unlikely to be accurate, but overall downhole trends might be reliable.

We also monitored mud gas chemistry in real time throughout riser drilling operations to document the composition and concentration of gas released from the formation as it was drilled. This method, used previously during International Continental Scientific Drilling Program drilling (e.g., Erzinger et al., 2006), was used in scientific ocean drilling for the first time during Expedition 319. One example of the value and reliability of these data comes from comparison of the drilling mud gas, cuttings, and wireline logging data in Subunit IIIB (Figs. F5, F8). Increased mud gas methane concentrations are clearly correlated with increased wood content in cuttings; gas concentrations are also tightly correlated with several intervals of low $V_{\mathrm{P}} / V_{\mathrm{S}}$ and Poisson's ratio observed in sonic velocity logs (Fig. F8). Because pore water geochemical analyses are not possible on cuttings and are difficult in lithified or low-porosity core samples, mud gas analysis offers a promising approach for characterizing formation fluids in future deeper riser drilling. These data are especially important for understanding hydrologic and geochemical processes associated with faulting and fluid flow. 


\section{Observatory installation and preparation}

\section{Dummy run}

The dummy run test in Hole C0010A simulated operational procedures for installation of planned permanent future observatories. The permanent observatories include three major components: bottomhole instruments, tubing to provide structural support for downhole cables and hydraulic lines, and a circulation obviation retrofit kit (CORK) wellhead (Becker and Davis, 2005), which lands at the casing hanger, seals the borehole, and suspends the instruments below (Fig. F12A, F12B). In this test, we successfully confirmed operational procedures to make up the bottom-hole instruments and lower them into the water, which went smoothly. We were initially concerned that the weak surface of the strainmeter might hit and be damaged by the guide funnel below the rotary table as the tubing below the strainmeter entered the ocean and was exposed to the Kuroshio Current. However by adjusting the length of tubing prior to assembly we were able to solve this problem by trial and error.

The instruments were subjected to significant vibration on the drill string as the Chikyu drifted to the site for reentry because of the Kuroshio Current. This resulted in damage to the accelerometer and loss of a seismometer and strainmeter during the two dummy runs. Before the experiment, vibration on the drill string was acknowledged as a potential issue but not emphasized as the primary concern. The tubing and the instrument string are much weaker than drill pipe, and therefore vibration was amplified in these weak sections through resonance. Effects were so strong that some vital parts of instruments (such as hinges and pivots in the seismometers) may not maintain their performance after installation in the hole, even if we could modify design of the instrument carrier to maintain its integrity during installation. In addition, we did not test the entire planned instrument string, which will include a CORK head and $>500 \mathrm{~m}$ of hydraulic tubing and cables. This experience necessitates a more complete evaluation of the observatory design and installation. Evaluation and modifications are necessary to address several issues, including: (1) sensor integrity under vibration, (2) resonance effects and stress in sections of the observatory under vibration, and (3) tolerance of downhole cable and hydraulic lines to stress and vibration. Acceleration data from the dummy run test in this expedition will provide valuable information for these evaluations.

There are also other options for installation of longterm observatories that should be considered. The smart plug installed in this expedition (see "Tempo- rary monitoring system") offers one encouraging option for intermediate to long-term emplacement of robust but simple retrievable observatories. In a modified smart plug incorporating a seismometer, continuous seismic observations for a period of $2 \mathrm{y}$ would be possible in conjunction with pressure and temperature observations. Such an installation would still require evaluation of effects from vibration on seismometers and pressure gauges because, like the bottom-hole instrument string for the dummy run test, the smart plug is run into the borehole using drill pipe. Another option would be to separate the tasks of lowering sensors into the hole from lowering the observatory to the seafloor in order to reduce effects from the ocean current-induced vibration. In this case, an observatory package that houses bottom-hole sensors and a downhole cable wound in a winch could be landed on the reentry funnel of the borehole, avoiding severe vibration of sensors and cables. The sensors could then be lowered to the bottom of the hole by wireline using the winch. Such an observation system has been developed for logging (Amitani et al., 2002) but is not used routinely in boreholes. Installation of cabled sensors into a borehole by controlled wireline has also been achieved (Stephen et al., 2003). In this case, the downhole cable was payed out under the seafloor station before reentry. This has the risk of damaging the cable by heave of the ship when the cable is lowered into the borehole. For any of these options, it is necessary to implement risk assessment in each stage of deployment.

\section{Temporary monitoring system}

After LWD, casing, and the dummy run test at Site C0010, we suspended the hole by installing a sensor package (smart plug) attached below a retrievable casing packer (Fig. F12C, F12D). The smart plug is a robust, retrievable, stand-alone instrument package designed with relatively short lead time in order to make use of suspended boreholes prior to final observatory installation. Although it is relatively simple, the smart plug at Site C0010 represents the first longterm monitoring in the NanTroSEIZE project and the first observatory element installed by the Chikyu. If successful, it will provide another tool for long-term hydrologic and/or thermal monitoring in ocean boreholes and short-term data at this site.

For the installation at Site C0010, the retrievable casing packer was placed above two screened casing joints that provide hydraulic communication with the megasplay fault zone (Fig. F12C). In this configuration, the smart plug will monitor pore pressure and temperature within the megasplay fault, and as a reference will also record the hydrostatic pressure (over- 
lying ocean) (Fig. F12C). The hole completion relies on cement at the base of the casing shoe and in the annulus in the lower part of the hole, and on collapse of soft sediment and thrust wedge material against the casing over the $\sim 400 \mathrm{~m}$ of annulus above the screens, to achieve hydraulic isolation from the sediments above and below, respectively. Upon recovery of the instruments (planned for 2010 or 2011), we will assess the efficacy of hydraulic isolation by comparison of the fault zone and hydrostatic pore pressure time series and by the response of the fault zone pore pressure to tidal loading (e.g., Wang and Davis, 1996). We also anticipate conducting a CBL as part of future operations to define the top of cement and to constrain the extent of formation collapse against the casing above the screens.

Despite strong ocean currents (up to $4.5 \mathrm{kt}$ and persisting to a depth of several hundred meters below sea level), the smart plug was successfully run to the wellhead and set inside the casing. However, even for installation of this relatively simple and short sensor package, we encountered problems with the Kuroshio Current; upon running the drill pipe to the surface, the running tool sheared off from the drill pipe at the $3 \frac{1}{2}$ inch tubing connection, presumably as a result of VIV in the water column. One key difference between the smart plug and many previous hydrologic observatory installations in ODP (e.g., Becker and Davis, 2005) is that data cannot be downloaded from the sensor package until it is retrieved with the packer using a drillship. Thus, we cannot assess whether damage to the electronics or pressure sensors was sustained during running to the wellhead or hole reentry prior to instrument recovery.

\section{Preliminary scientific assessment}

Riser drilling at Site C0009 during Expedition 319 allowed a number of new techniques and measurements. These included measurement of gas from drilling mud; analysis of sediment and rock cuttings; and measurement of in situ stress magnitude, formation pressure, and permeability. Important outcomes of Expedition 319 were an assessment of the scope and limitations of these new techniques and improved cuttings sample handling and processing methods. In addition, experience gained from riser drilling with weighted mud during Expedition 319 will be valuable in planning and executing future deep riser drilling. At the riserless Site C0010, the first observatory installation by the Chikyu was conducted. In addition, future observatory instruments and an instrument carrier were tested during run-in to evaluate their design. Knowledge gained from this expedition, in terms of both operations and science, will be valuable for future riser drilling expeditions and for observatory installation.

The goals of this expedition were numerous and involved a wide range of different drilling operations, including coring, drilling mud sampling, wireline logging, LWD/MWD, a VSP experiment involving a second vessel, and observatory installation. The aim was to drill at two primary sites over a period of 114 days including 27 contingency days: one riser drilling site within the forearc basin above the seismogenic part of the active plate boundary, and a riserless drill site in the shallow part of the major megasplay fault system. The scientific objectives were to further understand the processes and properties of the forearc and fault systems while also preparing for and installing observatory systems for long term monitoring of temperature, pore pressure, deformation, and seismicity.

\section{Success relative to planned objectives}

Site C0009 within the landward part of the Kumano forearc basin was successfully drilled to the planned total depth. Cuttings were collected for the entire riser drilled interval, with multiple sets in certain intervals. Core recovery was poor in the upper part of the cored section but overall provided material for shipboard analysis and postexpedition geotechnical studies at the depth of planned future observatory installation and for calibration of cuttings measurements and wireline logs. The three planned wireline logging runs were successfully completed to TD including, for the first time in IODP, the successful deployment of the MDT tool for in situ pore pressure and stress magnitude measurement. A late addition to the operational plan, a zero-offset and walkaway VSP experiment, was incorporated into the operational plan (although with a slightly reduced experiment) despite complex scheduling logistics. Ultimately, the walkaway VSP will provide improved resolution of seismic velocity around the borehole and also image the plate boundary and other structures beneath the borehole. The borehole was cased to $1540 \mathrm{~m} \mathrm{DSF}$, preserving the hole for future observatory installation.

Site C0010 was drilled through the shallow megasplay thrust fault near its updip terminus and overlying the hypothesized updip limit of the seismogenic plate boundary to $555 \mathrm{~m}$ LSF. Data collected were LWD/MWD (gamma ray and resistivity only) down the borehole and across the megasplay fault, including relogging of an interval because of poor data quality during bad weather. We were able to define major unit boundaries and the fault zone on the basis of the limited LWD/MWD data sets, guided by results of previous LWD and coring at nearby Site 
C0004. The borehole was cased with a screened interval spanning the megasplay fault zone and cemented as planned. Running of the dummy observatory sensor package to test conditions and adapt engineering design for future installations was hindered by current vibrations and loss of part of the package prior to reentry. Therefore, shock and acceleration data are available in the water column but not from reentry into the borehole. A temporary monitoring package (smart plug) was successfully installed to measure formation pore pressure and temperature within the megasplay fault zone and is programmed to record data until retrieval, anticipated in the next $1-2 \mathrm{y}$.

The integration of core, cuttings, log, and seismic data at and between the two Expedition 319 sites, combined with NanTroSEIZE Stage 1 sites, provides information about sediment properties, lithology, and structure at a wide range of sites and depths across the forearc basin and prism; allows interpretation of structure and development of the Kumano basin and forearc from the late Miocene to present; constrains the hydrological state of the basin and upper prism sediments from in situ measurements; and provides a comprehensive view of in situ stress variability (primarily orientation) across the forearc.

Additional time at the end of the expedition allowed the planned contingency operations to be assessed; LWD/MWD drilling of future coring Site NT1-07 (Site C0011), the primary site for Expedition 322, was chosen as the best science for the time and personnel available. This provided an important advance data set to guide the coring, downhole measurements, and sampling plan for Expedition 322. This is a contribution to the overall NanTroSEIZE program and also constitutes an example of successful operational and scientific flexibility that allowed the best use of contingency time. Site C0011 was drilled to $980 \mathrm{~m}$ DSF, collecting gamma ray and resistivity data (including resistivity images). These data are formally reported in Expedition 322 publications.

\section{Problems and challenges}

The wide range of different and new drilling operations during Expedition 319 involving different personnel, equipment, and potential problems resulted in a very long and complex planning process. It is therefore unsurprising that operations and logistics were complex during this expedition. At Site C0009, several operational problems were encountered during riser preparations and drilling, resulting in lost time. These included recovery of a lost BHA/DAT, riser system installation problems, and DPS malfunctions. However, with specific operations taking both more and less time than anticipated, Site C0009 drilling ultimately ended on schedule but used all allocated contingency time. The constantly changing drilling operations schedule also made planning and conducting the walkaway VSP experiment with Kairei very complicated and almost impossible. The flexibility of schedules and vessel availability will need to be reviewed carefully when planning future experiments of this kind.

An additional operational challenge we faced was in cementing both the riser and riserless boreholes. Successful cementing is essential to ensure sealing and good coupling between the casing and formation both for operations (i.e., successful deepening of the borehole and continued control of borehole pressure) and scientific objectives (e.g., integrity of observatory installations and obtaining high-quality VSP data). We encountered some problems in cementing both the $13 \% 8$ inch casing at Site C0009 and the $95 \%$ inch casing at Site C0010. In the case of the riser hole, cement loss and low cementing efficiency may be related to mud losses during drilling; merging of data from scientific measurements and operations in postexpedition research will be useful in evaluating this possibility. For the riserless site, some uncertainty in the cement job success resulted from problems with running and landing the cement dart. In both cases, the outcomes also highlight the value of running CBLs to define the top of cement and evaluate coupling of casing to the formation.

Riserless drilling of Site C0010 was operationally simple and took less time than originally scheduled, despite the high velocity of the Kuroshio Current (up to $5 \mathrm{kt}$ ) during operations and temporary evacuation during a typhoon. Vibrations induced by the current resulted in the destruction of one instrument and the loss of two others within the sensor package during the observatory dummy run. This reduces the amount of data available for future observatory installation planning but indicates the potential impact of the current on the drill string. The significant vibration sustained while running the instruments in the water column and through the Kuroshio Current may prompt a redesign of the observatory systems and deployment strategies.

This expedition was the first to process and analyze drilling mud samples, including gas and cuttings. Therefore, considerable planning was undertaken and patience and versatility on the part of the science and technical team were needed to analyze samples and maximize scientific achievements. In both cases, all groups worked toward providing valuable experimental guidelines for future IODP drilling mud sample handling.

Expedition 319 was also unusual in splitting the Science Party into two groups but working continuously 
and collectively on shipboard data analysis and report preparation, with four co-chief scientists and specialty coordinators working together across the halves of the expedition to unify the two groups and the scientific results. This aspect of Expedition 319 was extremely challenging for the co-chiefs, expedition project managers, and also for the science party members and required patience, cooperation, and scientific involvement from all parties both before and after shipboard participation. Improved Internet bandwidth for file sharing between shore-based and shipboard science groups will be essential to ensure the success of similar future expeditions. Experiences during this expedition indicate that the entire science party should meet prior to the expedition to improve planning and communication throughout the expedition. This model will be required for future riser drilling operations; therefore, the experience and lessons learned during Expedition 319 will be critical in guiding and planning these efforts.

\section{References}

Amitani, Y., Kyo, M., Hashimoto, K., Shimura, T., and Sawa, T., 2002. Borehole Reentry System "BENKEI." Proc. Int. Offshore Polar Eng. Conf., 12:116-121.

Ando, M., 1975. Source mechanisms and tectonic significance of historical earthquakes along the Nankai Trough, Japan. Tectonophysics, 27(2):119-140. doi:10.1016/0040-1951(75)90102-X

Araki, E., Byrne, T., McNeill, L., Saffer, D., Eguchi, N., Takahashi, K., and Toczko, S., 2009. NanTroSEIZE Stage 2: NanTroSEIZE riser/riserless observatory. IODP Sci. Prosp., 319. doi:10.2204/iodp.sp.319.2009

Ashi, J., Lallemant, S., Masago, H., and the Expedition 315 Scientists, 2008. NanTroSEIZE Stage 1A: NanTroSEIZE megasplay riser pilot. IODP Prel. Rept., 315. doi:10.2204/iodp.pr.315.2008

Ashi, J., Kuramoto, S., Morita, S., Tsunogai, U., Goto, S., Kojima, S., Okamoto, T., Ishimura, T., Ijiri, A., Toki, T., Kudo, S., Asai, S., and Utsumi, M., 2002. Structure and cold seep of the Nankai accretionary prism off Kumano-outline of the off Kumano survey during YK01-04 Leg 2 cruise. JAMSTEC J. Deep Sea Res., 20:1-8. (in Japanese, with abstract in English)

Athy, L.F., 1930. Density, porosity, and compaction of sedimentary rocks. AAPG Bull., 14:1-24.

Baba, T., and Cummins, P.R., 2005. Contiguous rupture areas of two Nankai Trough earthquakes revealed by high-resolution tsunami waveform inversion. Geophys. Res. Lett., 32(8):L08305. doi:10.1029/2004GL022320

Baba, T., Cummins, P.R., and Hori, T., 2005. Compound fault rupture during the 2004 off the Kii Peninsula earthquake (M 7.4) inferred from highly resolved coseismic sea-surface deformation. Earth, Planets Space, 57(3):167-172.

Baba, T., Cummins, P.R., Hori, T., and Kaneda, Y., 2006. High precision slip distribution of the 1944 Tonankai earthquake inferred from tsunami waveforms: possible slip on a splay fault. Tectonophysics, 426(1-2):119-134. doi:10.1016/j.tecto.2006.02.015

Barton, C.A., and Zoback, M.D., 1994. Stress perturbations associated with active faults penetrated by boreholes: possible evidence for near-complete stress drop and a new technique for stress magnitude measurement. $J$. Geophys. Res., [Solid Earth], 99(B5):9373-9390. doi:10.1029/93JB03359

Barton, C.A., Zoback, M.D., and Moos, D., 1995. Fluid flow along potentially active faults in crystalline rock. Geology, 23(8):683-686. doi:10.1130/00917613(1995)023<0683:FFAPAF>2.3.CO;2

Becker, K., and Davis, E.E., 2005. A review of CORK designs and operations during the Ocean Drilling Program. In Fisher, A.T., Urabe, T., Klaus, A., and the Expedition 301 Scientists, Proc. IODP, 301: College Station, TX (Integrated Ocean Drilling Program Management International, Inc.). doi:10.2204/iodp.proc.301.104.2005

Byrne, D.E., Davis, D.M., and Sykes, L.R., 1988. Loci and maximum size of thrust earthquakes and the mechanics of the shallow region of subduction zones. Tectonics, 7(4):833-857. doi:10.1029/TC007i004p00833

Conin, M., Bourlange, S., Henry, P., and the IODP Expedition 314/315/316 Scientific Party, 2008. Interpretation of LWD resistivity from Nankai accretionary wedge in the light of clay physico-chemical properties. Eos, Trans. Am. Geophys. Union, 89(53)(Suppl.):T31B-1999. (Abstract) http://www.agu.org/meetings/fm08/ waisfm08.html

Erzinger, J., Wiersberg, T., and Zimmer, M., 2006. Real-time mud gas logging and sampling during drilling. Geofluids, 6(3):225-233. doi:10.1111/j.14688123.2006.00152.x

Expedition 314 Scientists, 2009. Expedition 314 Site C0004. In Kinoshita, M., Tobin, H., Ashi, J., Kimura, G., Lallemant, S., Screaton, E.J., Curewitz, D., Masago, H., Moe, K.T., and the Expedition 314/315/316 Scientists, Proc. IODP, 314/315/316: Washington, DC (Integrated Ocean Drilling Program Management International, Inc.). doi:10.2204/iodp.proc.314315316.116.2009

Expedition 315 Scientists, 2009. Expedition 315 Site C0002. In Kinoshita, M., Tobin, H., Ashi, J., Kimura, G., Lallemant, S., Screaton, E.J., Curewitz, D., Masago, H., Moe, K.T., and the Expedition 314/315/316 Scientists, Proc. IODP, 314/315/316: Washington, DC (Integrated Ocean Drilling Program Management International, Inc.). doi:10.2204/iodp.proc.314315316.124.2009

Expedition 316 Scientists, 2009. Expedition 316 Site C0004. In Kinoshita, M., Tobin, H., Ashi, J., Kimura, G., Lallemant, S., Screaton, E.J., Curewitz, D., Masago, H., Moe, K.T., and the Expedition 314/315/316 Scientists, Proc. IODP, 314/315/316: Washington, DC (Integrated Ocean Drilling Program Management International, Inc.). doi:10.2204/iodp.proc.314315316.133.2009

Hart, B.S., Flemings, P.B., and Deshpande, A., 1995. Porosity and pressure: role of compaction disequilibrium in the development of geopressures in a Gulf Coast Pleistocene basin. Geology, 23(1):45-48. doi:10.1130/00917613(1995)023<0045:PAPROC >2.3.CO;2 
Heki, K., 2007. Secular, transient and seasonal crustal movements in Japan from a dense GPS array: implication for plate dynamics in convergent boundaries. In Dixon, T., and Moore, C. (Eds.), The Seismogenic Zone of Subduction Thrust Faults: New York (Columbia Univ. Press), 512-539.

Hickman, S., Zoback, M., and Ellsworth, W., 2004. Introduction to special section: preparing for the San Andreas Fault Observatory at depth. Geophys. Res. Lett., 31(12):L12S01. doi:10.1029/2004GL020688

Hori, T., Kato, N., Hirahara, K., Baba, T., and Kaneda, Y., 2004. A numerical simulation of earthquake cycles along the Nankai Trough in southwest Japan: lateral variation in frictional property due to the slab geometry controls the nucleation position. Earth Planet. Sci. Lett., 228(3-4):215-226. doi:10.1016/j.epsl.2004.09.033

Ichinose, G.A., Thio, H.K., Somerville, P.G., Sato, T., and Ishii, T., 2003. Rupture process of the 1944 Tonankai earthquake $\left(M_{s} 8.1\right)$ from the inversion of teleseismic and regional seismograms. J. Geophys. Res., 108(B10):2497. doi:10.1029/2003JB002393

Isozaki, Y., and Itaya, T., 1990. Chronology of Sanbagawa metamorphism. J. Metamorph. Geol., 8(4):401-411. doi:10.1111/j.1525-1314.1990.tb00627.x

Ito, Y., Obara, K., Shiomi, K., Sekine, S., and Hirose, H., 2007. Slow earthquakes coincident with episodic tremors and slow slip events. Science, 315(5811):503-506. doi:10.1126/science.1134454

Kikuchi, M., Nakamura, M., and Yoshikawa, K., 2003. Source rupture processes of the 1944 Tonankai earthquake and the 1945 Mikawa earthquake derived from low-gain seismograms. Earth, Planets Space, 55(4):159_ 172.

Kimura, G., Screaton, E.J., Curewitz, D., and the Expedition 316 Scientists, 2008. NanTroSEIZE Stage 1A: NanTroSEIZE shallow megasplay and frontal thrusts. IODP Prel. Rept., 316. doi:10.2204/iodp.pr.316.2008

Kinoshita, M., Tobin, H., Ashi, J., Kimura, G., Lallemant, S., Screaton, E.J., Curewitz, D., Masago, H., Moe, K.T., and the Expedition 314/315/316 Scientists, 2009. Proc. IODP, 314/315/316: Washington, DC (Integrated Ocean Drilling Program Management International, Inc.). doi:10.2204/iodp.proc.314315316.2009

Kinoshita, M., Tobin, H., Moe, K.T., and the Expedition 314 Scientists, 2008. NanTroSEIZE Stage 1A: NanTroSEIZE LWD transect. IODP Prel. Rept., 314. doi:10.2204/ iodp.pr.314.2008

Lay, T., Kanamori, H., Ammon, C.J., Nettles, M., Ward, S.N., Aster, R.C., Beck, S.L., Bilek, S.L., Brudzinski, M.R., Butler, R., DeShon, H.R., Ekström, G., Satake, K., and Sipkin, S., 2005. The great Sumatra-Andaman earthquake of 26 December 2004. Science, 308(5725):11271133. doi:10.1126/science.1112250

Ma, K., 2005. Slip zone and energetic of a large earthquake from seismological modeling and fault core of TCDP. Eos, Trans. Am. Geophys. Union, 86(52):T43D-02. (Abstract)

Martini, E., 1971. Standard Tertiary and Quaternary calcareous nannoplankton zonation. In Farinacci, A. (Ed.),
Proc. 2nd Int. Conf. Planktonic Microfossils Roma: Rome (Ed. Tecnosci.), 2:739-785.

Miyazaki, S., and Heki, K., 2001. Crustal velocity field of southwest Japan: subduction and arc-arc collision. J. Geophys. Res., 106(B3):4305-4326. doi:10.1029/ 2000JB900312

Moore, G.F., Bangs, N.L., Taira, A., Kuramoto, S., Pangborn, E., and Tobin, H.J., 2007. Three-dimensional splay fault geometry and implications for tsunami generation. Science, 318(5853):1128-1131. doi:10.1126/science.1147195

Moore, G.F., Park, J.-O., Bangs, N.L., Gulick, S.P., Tobin, H.J., Nakamura, Y., Sato, S., Tsuji, T., Yoro, T., Tanaka, H., Uraki, S., Kido, Y., Sanada, Y., Kuramoto, S., and Taira, A., 2009. Structural and seismic stratigraphic framework of the NanTroSEIZE Stage 1 transect. In Kinoshita, M., Tobin, H., Ashi, J., Kimura, G., Lallemant, S., Screaton, E.J., Curewitz, D., Masago, H., Moe, K.T., and the Expedition 314/315/316 Scientists, Proc. IODP, 314/315/316: Washington, DC (Integrated Ocean Drilling Program Management International, Inc.). doi:10.2204/iodp.proc.314315316.102.2009

Moore, G.F., Taira, A., Klaus, A., Becker, L., Boeckel, B., Cragg, B.A., Dean, A., Fergusson, C.L., Henry, P., Hirano, S., Hisamitsu, T., Hunze, S., Kastner, M., Maltman, A.J., Morgan, J.K., Murakami, Y., Saffer, D.M., SánchezGómez, M., Screaton, E.J., Smith, D.C., Spivack, A.J., Steurer, J., Tobin, H.J., Ujiie, K., Underwood, M.B., and Wilson, M., 2001. New insights into deformation and fluid flow processes in the Nankai Trough accretionary prism: results of Ocean Drilling Program Leg 190. Geochem., Geophys., Geosyst., 2(10):1058. doi:10.1029/ 2001GC000166

Moore, G.F., Taira, A., Klaus, A., et al., 2001. Proc. ODP, Init. Repts., 190: College Station, TX (Ocean Drilling Program). doi:10.2973/odp.proc.ir.190.2001

Moore, J.C., and Saffer, D., 2001. Updip limit of the seismogenic zone beneath the accretionary prism of southwest Japan: an effect of diagenetic to low-grade metamorphic processes and increasing effective stress. Geology, 29(2):183-186. doi:10.1130/00917613(2001)029<0183:ULOTSZ >2.0.CO;2

Nakanishi, A., Takahashi, N., Park, J.-O., Miura, S., Kodaira, S., Kaneda, Y., Hirata, N., Iwasaki, T., and Nakamura, M., 2002. Crustal structure across the coseismic rupture zone of the 1944 Tonankai earthquake, the central Nankai Trough seismogenic zone. J. Geophys. Res., 107(B1):2007. doi:10.1029/2001JB000424

Obana, K., Kodaira, S., Mochizuki, K., and Shinohara, M., 2001. Micro-seismicity around the seaward updip limit of the 1946 Nankai earthquake dislocation area. Geophys. Res. Lett., 28(12):2333-2336. doi:10.1029/ 2000GL012794

Obara, K., Hirose, H., Yamamizu, F., and Kasahara, K., 2004. Episodic slow slip events accompanied by nonvolcanic tremors in southwest Japan subduction zone. Geophys. Res. Lett., 31:L23602. doi:10.1029/ 2004GL020848

Obara, K., and Ito, Y., 2005. Very low frequency earthquakes excited by the 2004 off the Kii Peninsula earth- 
quakes: a dynamic deformation process in the large accretionary prism. Earth, Planets Space, 57(4):321-326.

Park, J.-O., Tsuru, T., Kodaira, S., Cummins, P.R., and Kaneda, Y., 2002. Splay fault branching along the Nankai subduction zone. Science, 297(5584):1157-1160. doi:10.1126/science.1074111

Raffi, I., Backman, J., Fornaciari, E., Pälike, H., Rio, D., Lourens, L., and Hilgen, F., 2006. A review of calcareous nannofossil astrobiochronology encompassing the past 25 million years. Quat. Sci. Rev., 25(23-24):3113-3137. doi:10.1016/j.quascirev.2006.07.007

Ruff, L., and Kanamori, H., 1983. Seismic coupling and uncoupling at subduction zones. Tectonophysics, 99(24):99-117. doi:10.1016/0040-1951(83)90097-5

Saffer, D.M., and Marone, C., 2003. Comparison of smectite- and illite-rich gouge frictional properties: application to the updip limit of the seismogenic zone along subduction megathrusts. Earth Planet. Sci. Lett., 215(12):219-235. doi:10.1016/S0012-821X(03)00424-2

Saffer, D.M., 2003. Pore pressure development and progressive dewatering in underthrust sediments at the Costa Rican subduction margin: comparison with northern Barbados and Nankai. J. Geophys. Res., 108(B5):22612276. doi:10.1029/2002JB001787

Saito, S., Underwood, M.B., and Kubo, Y., 2009. NanTroSEIZE Stage 2: subduction inputs. IODP Sci. Prosp., 322. doi:10.2204/iodp.sp.322.2009

Seno, T., Stein, S., and Gripp, A.E., 1993. A model for the motion of the Philippine Sea plate consistent with NUVEL-1 and geological data. J. Geophys. Res., 98(B10):17941-17948. doi:10.1029/93JB00782

Stephen, R.A., Spiess, F.N., Collins, J.A., Hildebrand, J.A., Orcutt, J.A., Peal, K.R., Vernon, F.L., and Wooding, F.B., 2003. Ocean seismic network pilot experiment. Geochem., Geophys., Geosyst., 4(10):1092. doi:10.1029/ 2002GC000485

Strasser, M., Moore, G.F., Kimura, G., Kitamura, Y., Kopf, A.J., Lallemant, S., Park, J.-O., Screaton, E.J., Su, X., Underwood, M.B., and Zhao, X., 2009. Origin and evolution of a splay fault in the Nankai accretionary wedge. Nat. Geosci., 2(9):648-652. doi:10.1038/ngeo609

Taira, A., Katto, J., Tashiro, M., Okamura, M., and Kodama, K., 1988. The Shimanto Belt in Shikoku, Japan: evolution of Cretaceous to Miocene accretionary prism. Mod. Geol., 12:5-46.

Tanioka, Y., and Satake, K., 2001. Detailed coseismic slip distribution of the 1944 Tonankai earthquake estimated from tsunami waveforms. Geophys. Res. Lett., 28(6):1075-1078. doi:10.1029/2000GL012284

Tobin, H., Kinoshita, M., Ashi, J., Lallemant, S., Kimura, G., Screaton, E.J., Moe, K.T., Masago, H., Curewitz, D., and the Expedition 314/315/316 Scientists 2009. NanTroSEIZE Stage 1 expeditions: introduction and synthesis of key results. In Kinoshita, M., Tobin, H., Ashi, J., Kimura, G., Lallemant, S., Screaton, E.J., Curewitz, D., Masago, H., Moe, K.T., and the Expedition 314/315/316 Scientists, Proc. IODP, 314/315/316: Washington, DC (Integrated Ocean Drilling Program Management International, Inc.). doi:10.2204/

iodp.proc.314315316.101.2009

Tobin, H.J., and Kinoshita, M., 2006a. Investigations of seismogenesis at the Nankai Trough, Japan. IODP Sci. Prosp., NanTroSEIZE Stage 1. doi:10.2204/ iodp.sp.nantroseize1.2006

Tobin, H.J., and Kinoshita, M., 2006b. NanTroSEIZE: the IODP Nankai Trough Seismogenic Zone Experiment. Sci. Drill., 2:23-27. doi:10.2204/iodp.sd.2.06.2006

Underwood, M.B., Saito, S., Kubo, Y., and the Expedition 322 Scientists, 2009. NanTroSEIZE Stage 2: subduction inputs. IODP Prel. Rept., 322. doi:10.2204/

iodp.pr.322.2009

Wang, K., and Davis, E.E., 1996. Theory for the propagation of tidally induced pore pressure variations in layered subseafloor formations. J. Geophys. Res., 101(B5):11483-11496. doi:10.1029/96JB00641

Wang, K., and Hu, Y., 2006. Accretionary prisms in subduction earthquake cycles: the theory of dynamic Coulomb wedge. J. Geophys. Res., 111(B6):B06410. doi:10.1029/ 2005JB004094

Wiersberg, T., and Erzinger, J., 2007. A helium isotope cross-section study through the San Andreas Fault at seismogenic depths. Geochem., Geophys., Geosyst., 8(1):Q01002. doi:10.1029/2006GC001388

Yamano, M., Kinoshita, M., Goto, S., and Matsubayashi, O., 2003. Extremely high heat flow anomaly in the middle part of the Nankai Trough. Phys. Chem. Earth, 28(911):487-497. doi:10.1016/S1474-7065(03)00068-8

Zoback, M.D., 2007. Reservoir Geomechanics: Cambridge (Cambridge Univ. Press).

Publication: 31 August 2010 MS 319-101 
Figure F1. A. Map of study area showing drill sites. Green squares = Expedition 319, red circles = NanTroSEIZE Stage 1, black box $=$ location of 2006 three-dimensional seismic reflection data acquisition, black line $=$ KR0108-5 two-dimensional seismic profile, yellow arrows = estimated far-field vectors between Philippine Sea plate and Japan (Seno et al., 1993; Heki, 2007), stars = epicentral location of great earthquakes. Inset shows location of Nankai Trough around the drill sites. (Continued on next page.)

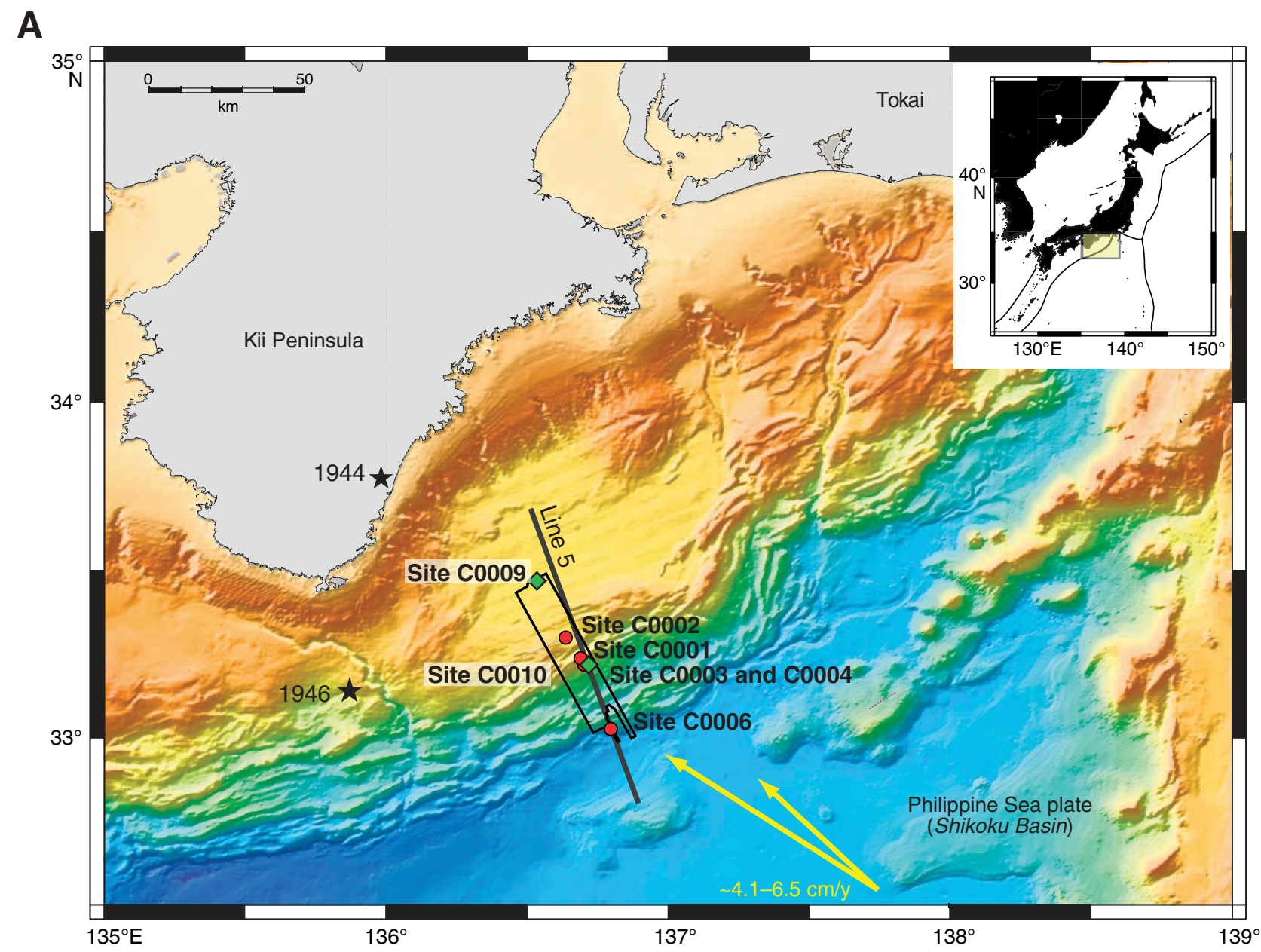


Figure F1 (continued). B. Map of drill sites, details of 1944 earthquake slip, and coseismic very low frequency earthquakes (VLFs). Contours = estimated slip during the 1944 event (0.5 m intervals) (Kikuchi et al., 2003), red box $=$ region of recorded VLFs (Obara and Ito, 2005).

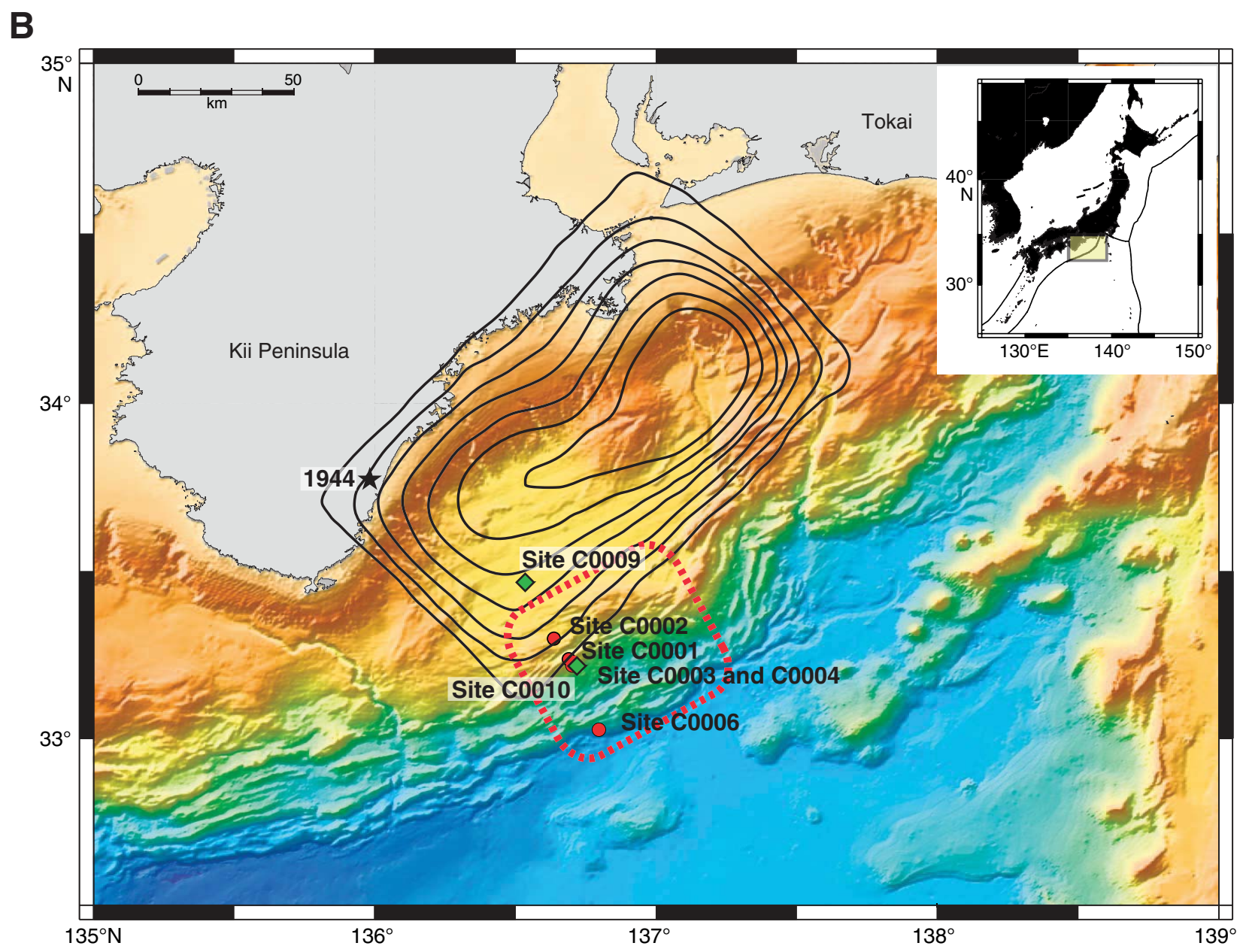


Figure F2. Interpreted seismic line from Park et al. (2002) showing drill site locations. Location shown in Figure F1A.

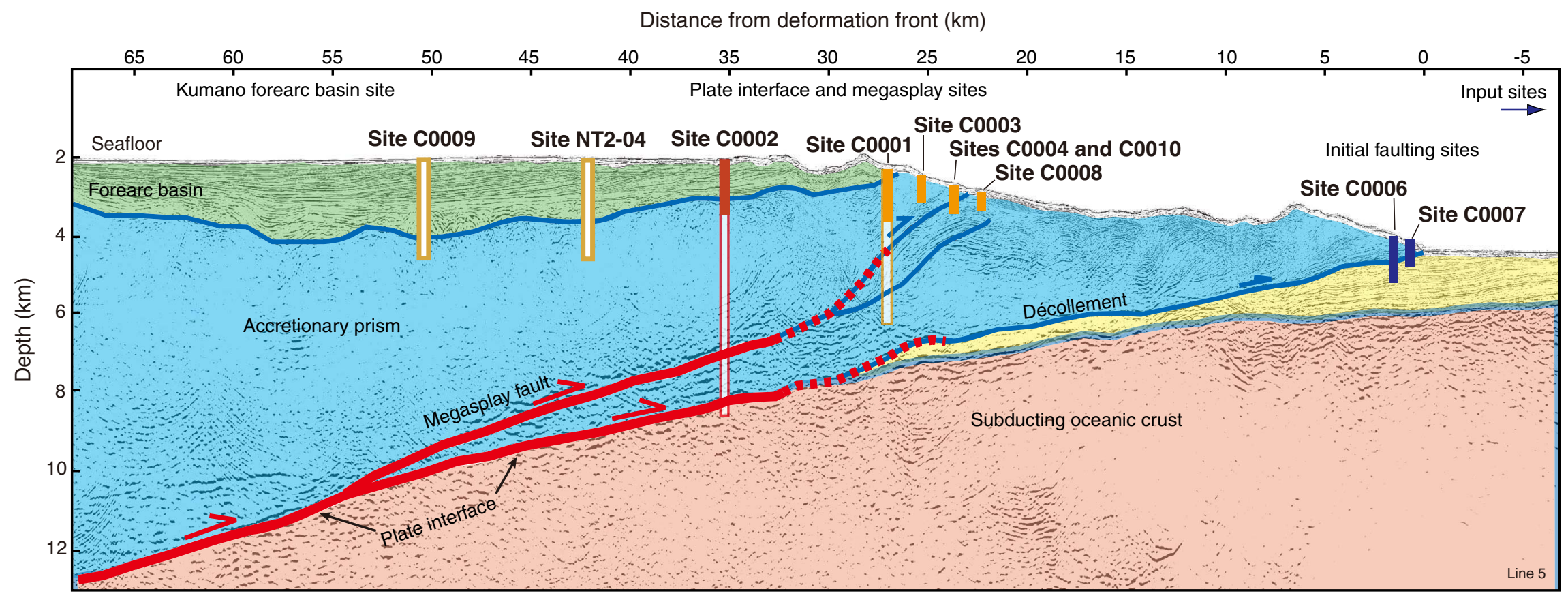


Figure F3. Seismic line from three-dimensional volume showing selected NanTroSEIZE drill site locations, including those from Expedition 319 (Araki et al., 2009).

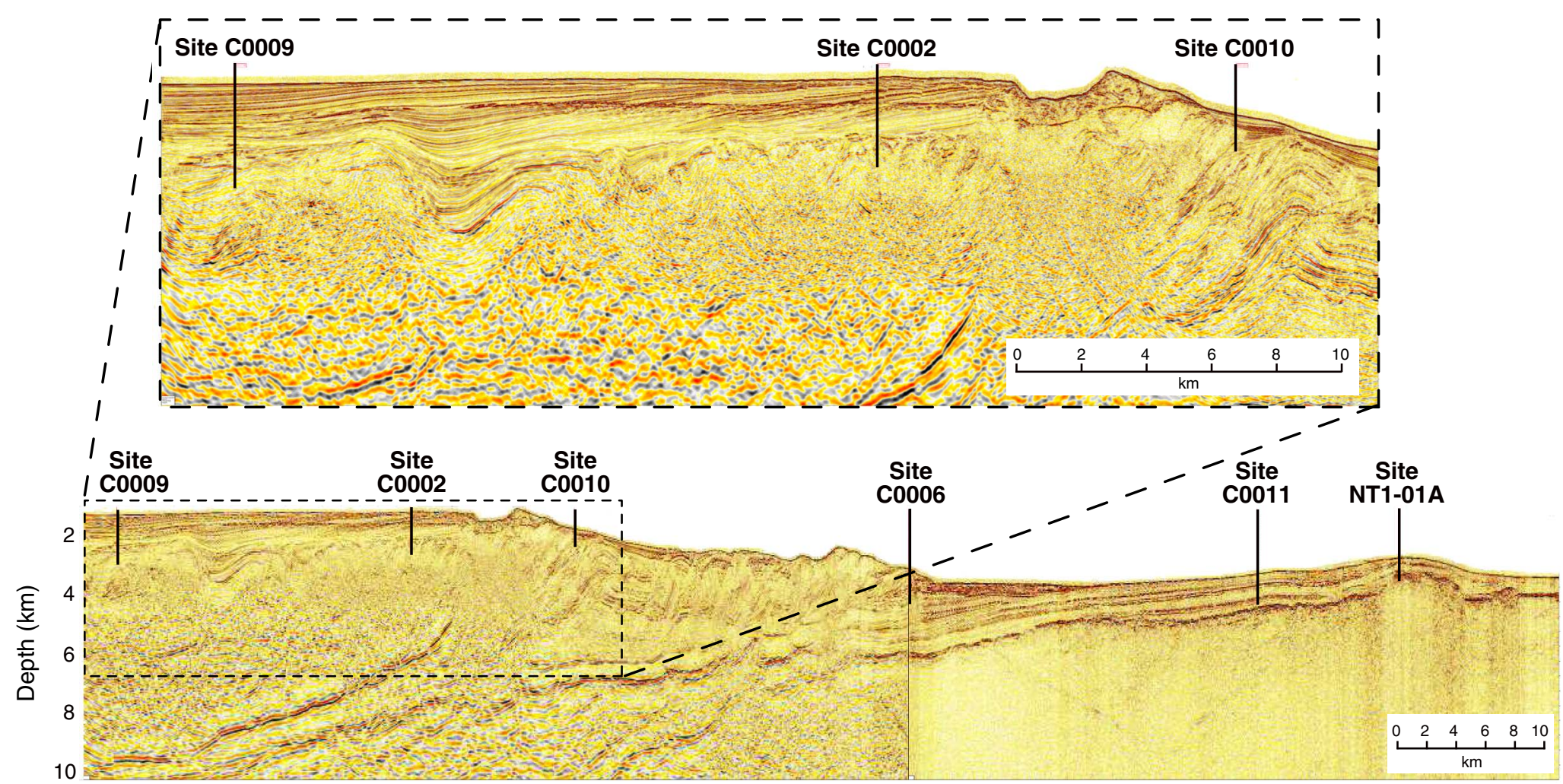


Figure F4. A. Seismic section showing location of Site C0009, including several regional seismic surfaces interpreted within the Kumano Basin (see text for discussion). VE = vertical exaggeration. (Continued on next page.)

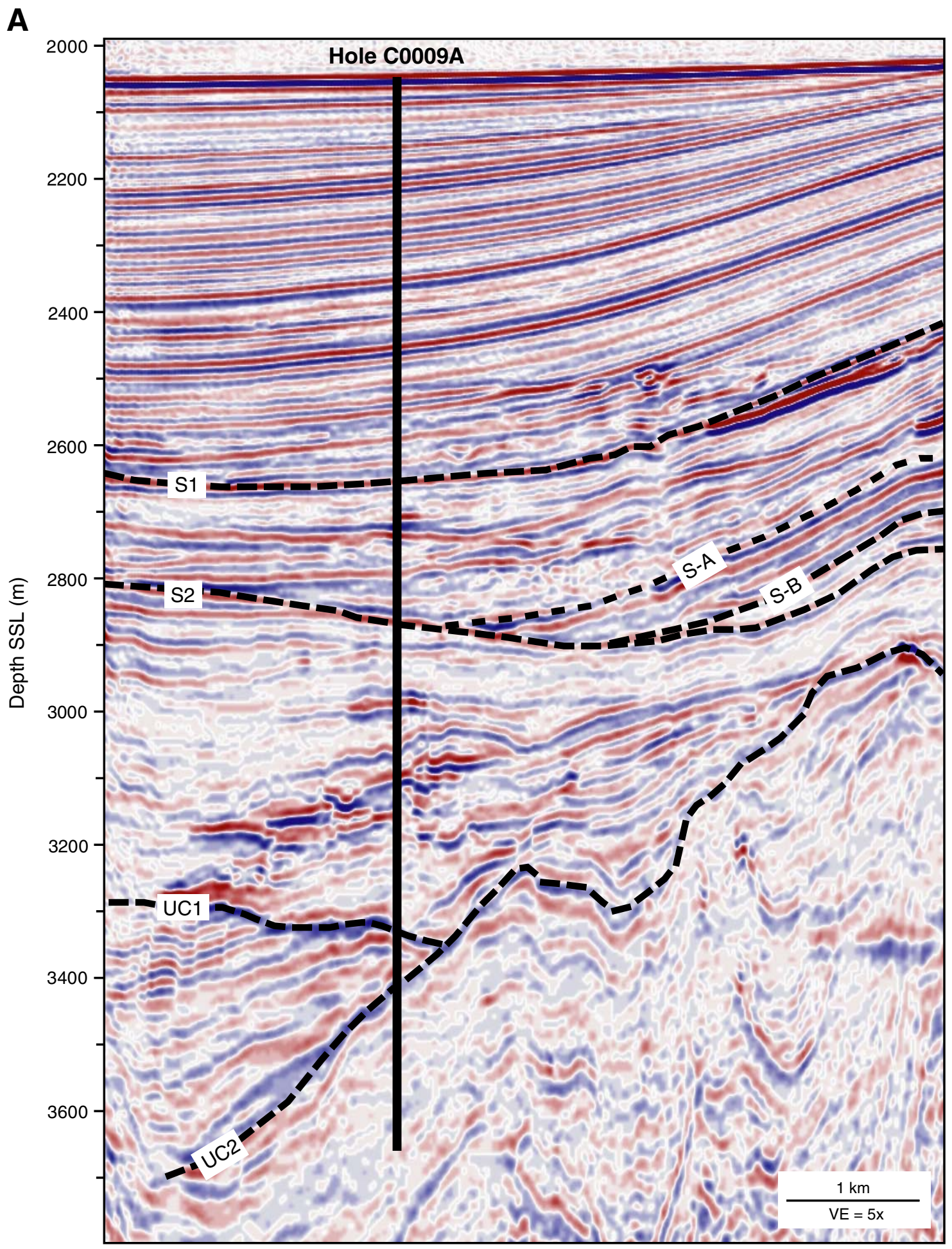




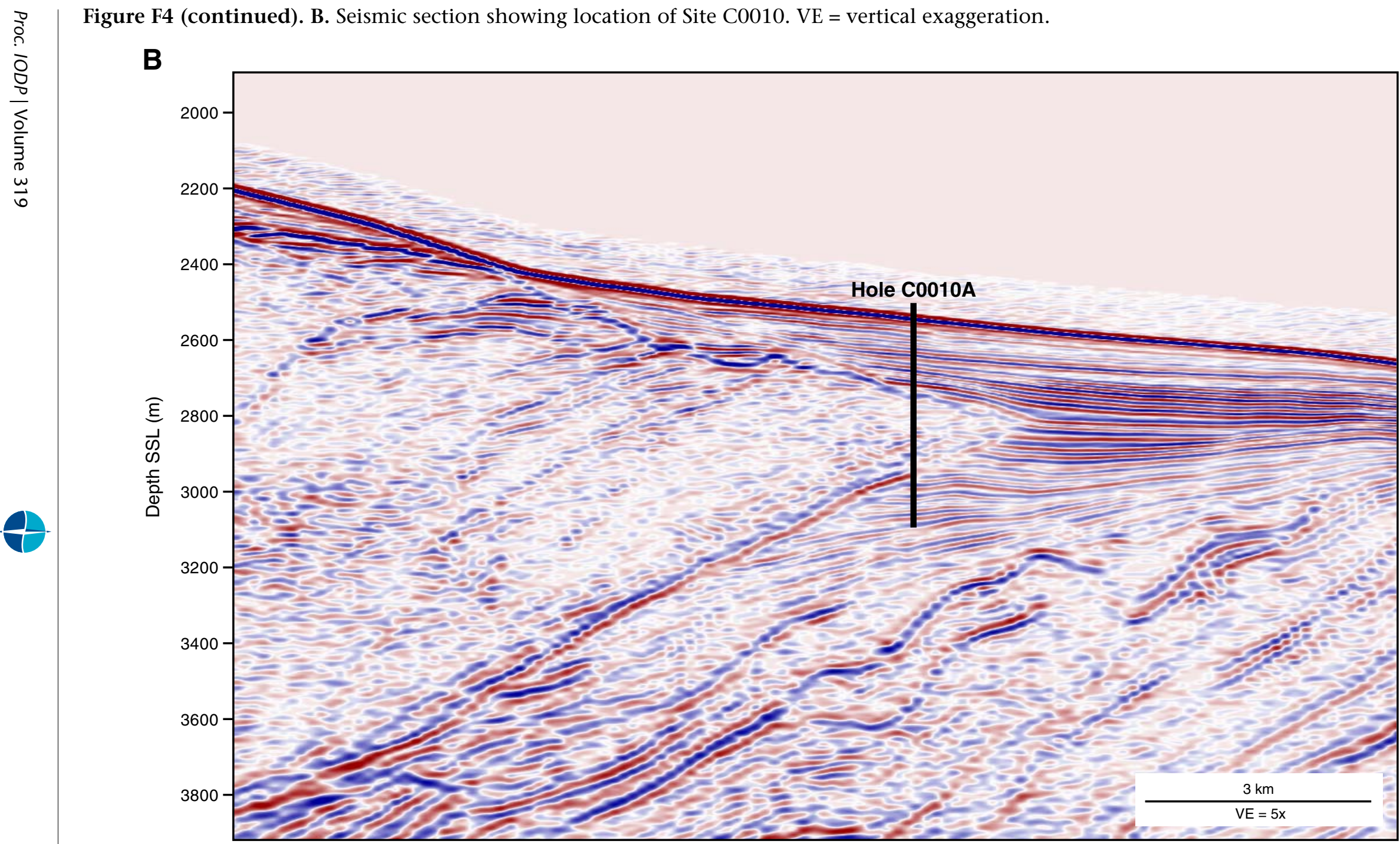


Figure F5. A. Site summary diagram for Site C0009 showing wireline logs and cuttings data from 700 to 1600 mbsf. SP = spontaneous potential, LOI $=$ loss on ignition, FMI = Formation MicroImager. (Continued on next page.)

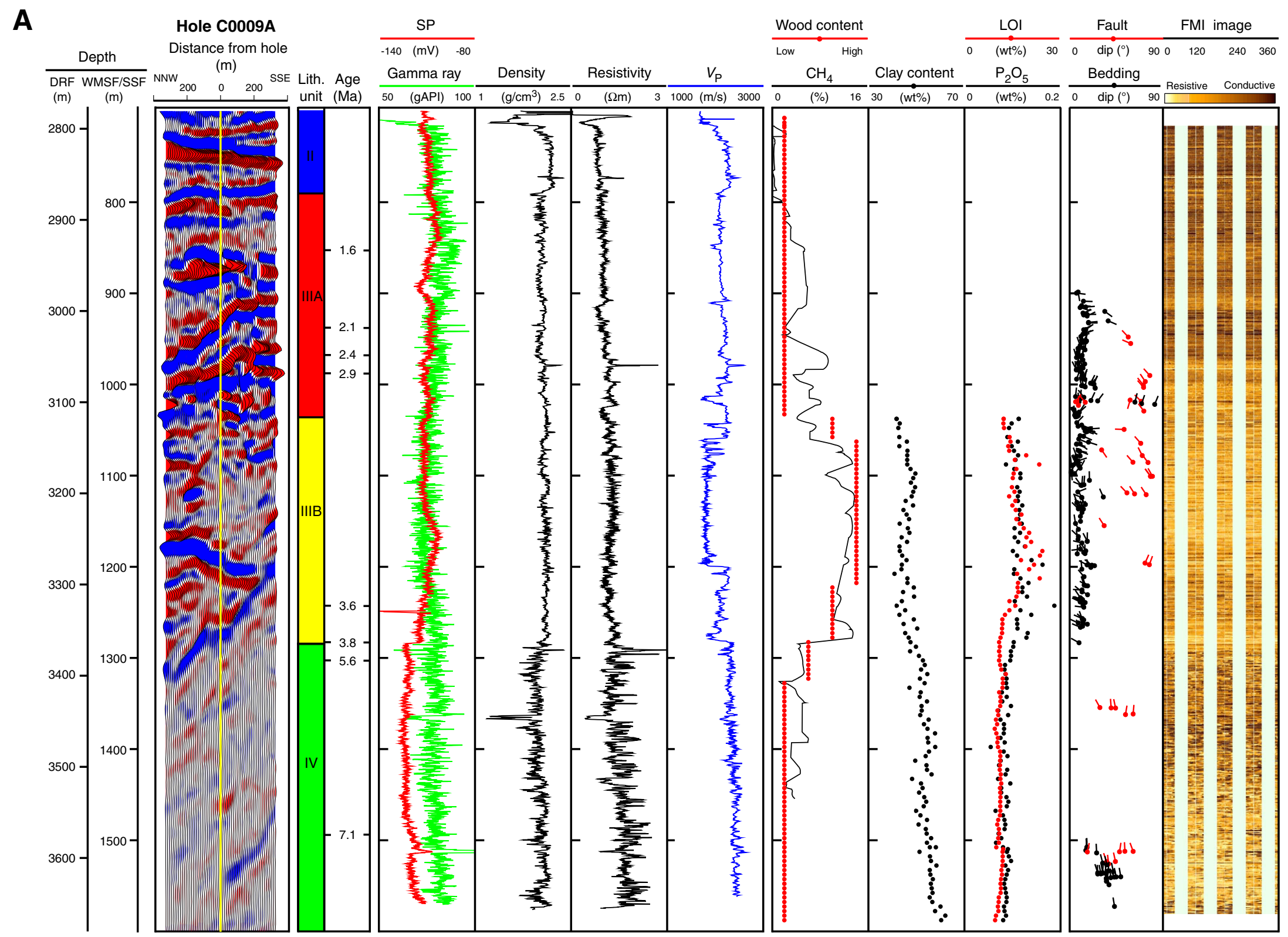


Figure F5 (continued). B. Site C0009 site summary diagram from 1510 to $1594 \mathrm{~m}$ CSF showing cuttings, core, and log data. PEF = photoelectric effect, $\mathrm{SP}=$ spontaneous potential, $\mathrm{MAD}=$ moisture and density.

B

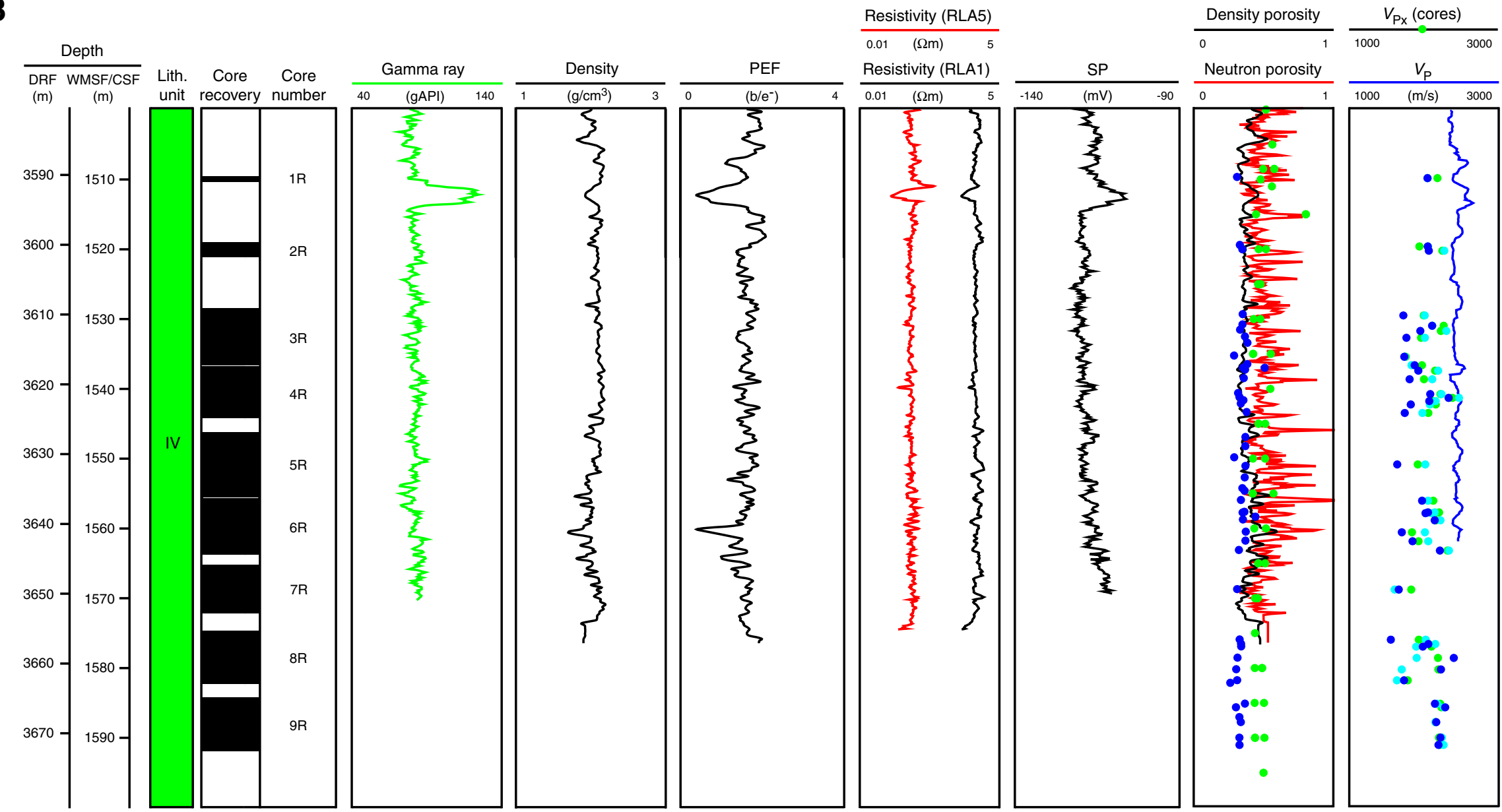


Figure F6. A. Detailed seismic line at Site C0009 as in Figure F4, with lithologic units and ages overlain. VE = vertical exaggeration. (Continued on next two pages.)

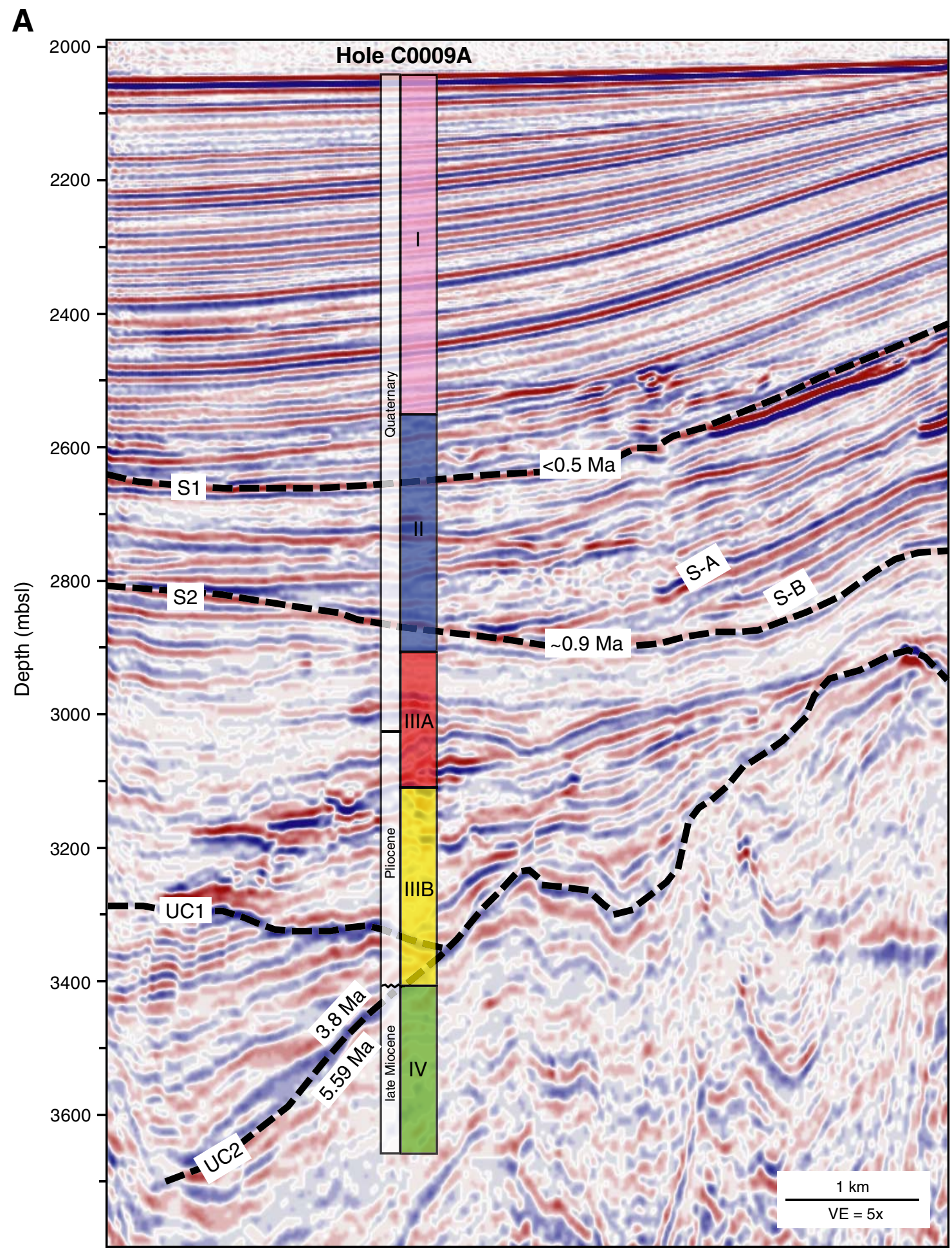


Figure F6 (continued). B. Regional seismic line showing correlation between Sites C0009 and C0002, including stratigraphic columns. VE = vertical exaggeration. (Continued on next page.)

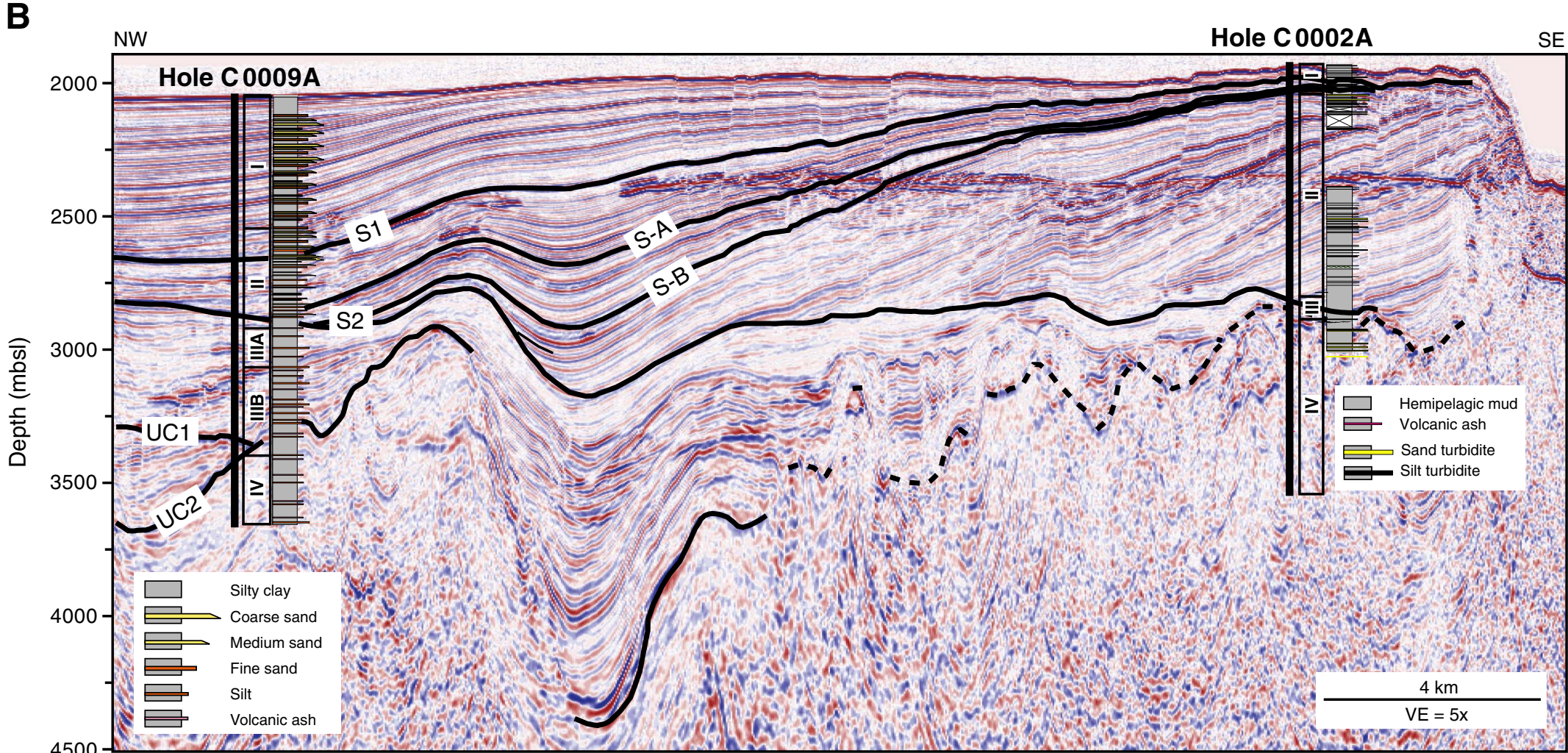


Figure F6 (continued). C. Interpretation of seismic profile in Figure F6B, showing lithologic units and ages. Inset shows detail of Units III-IV at Site C0002. VE = vertical exaggeration.

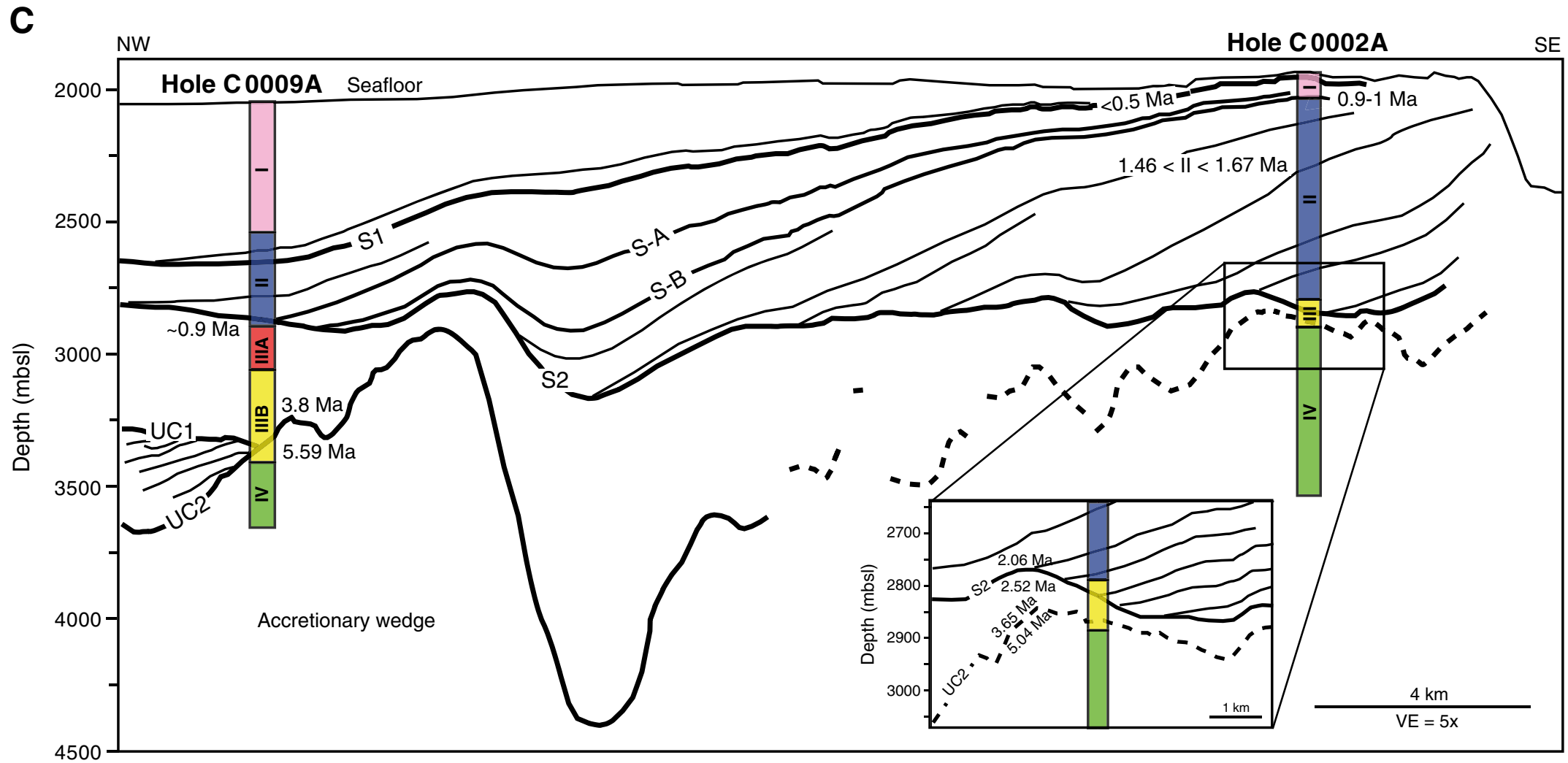


Figure F7. Map showing orientations of maximum horizontal stress $\left(S_{\mathrm{Hmax}}\right)$ inferred from borehole breakouts (see also Kinoshita et al., 2008). At Site C0002, red line $=$ orientation in forearc basin sediments, blue line = orientation in underlying accretionary prism. GPS = Global Positioning System.

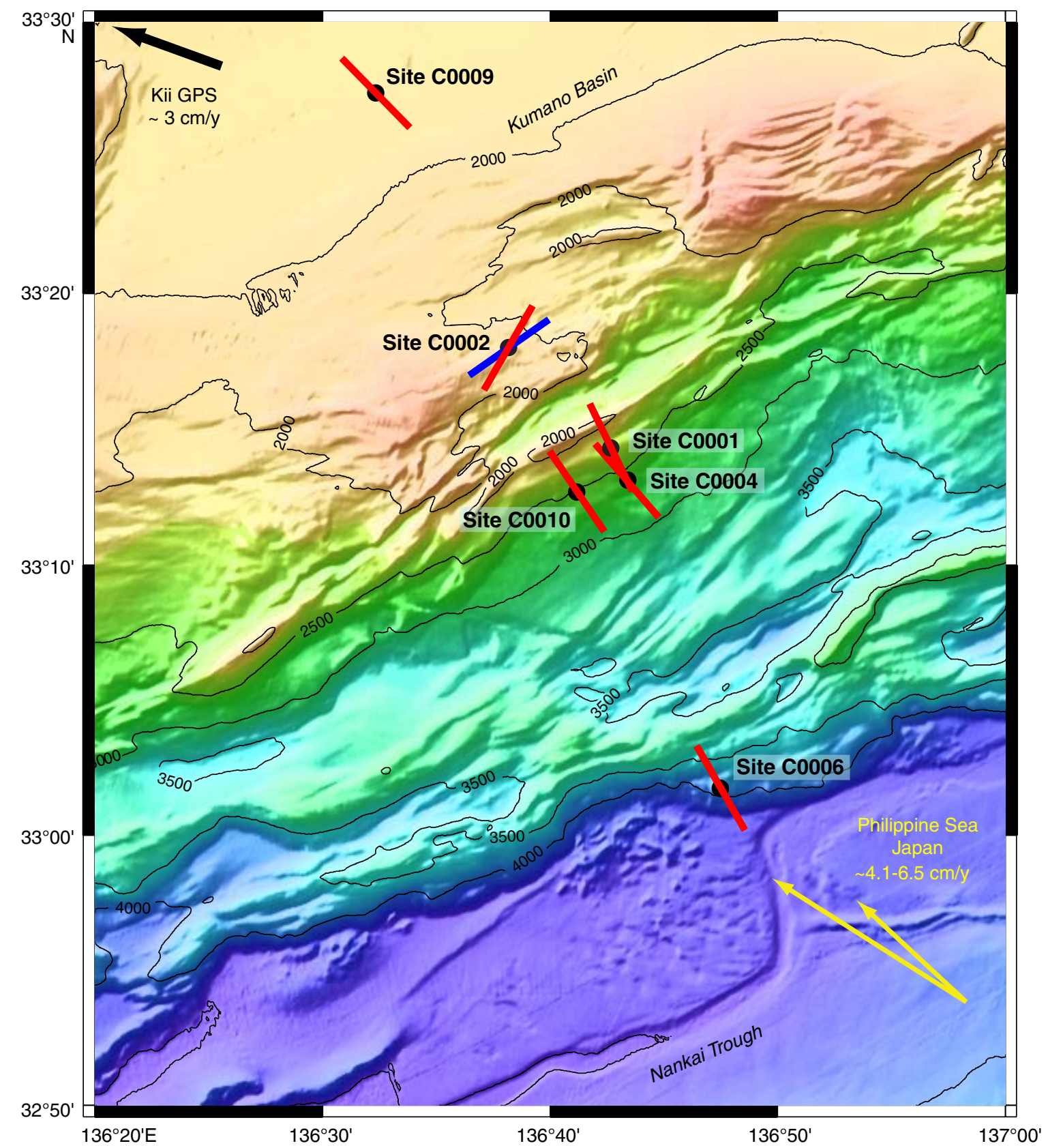


Figure F8. $V_{\mathrm{p}} / V_{\mathrm{S}}$ ratio, $P$-wave velocity and resistivity, and mud gas concentrations, Site C0009.

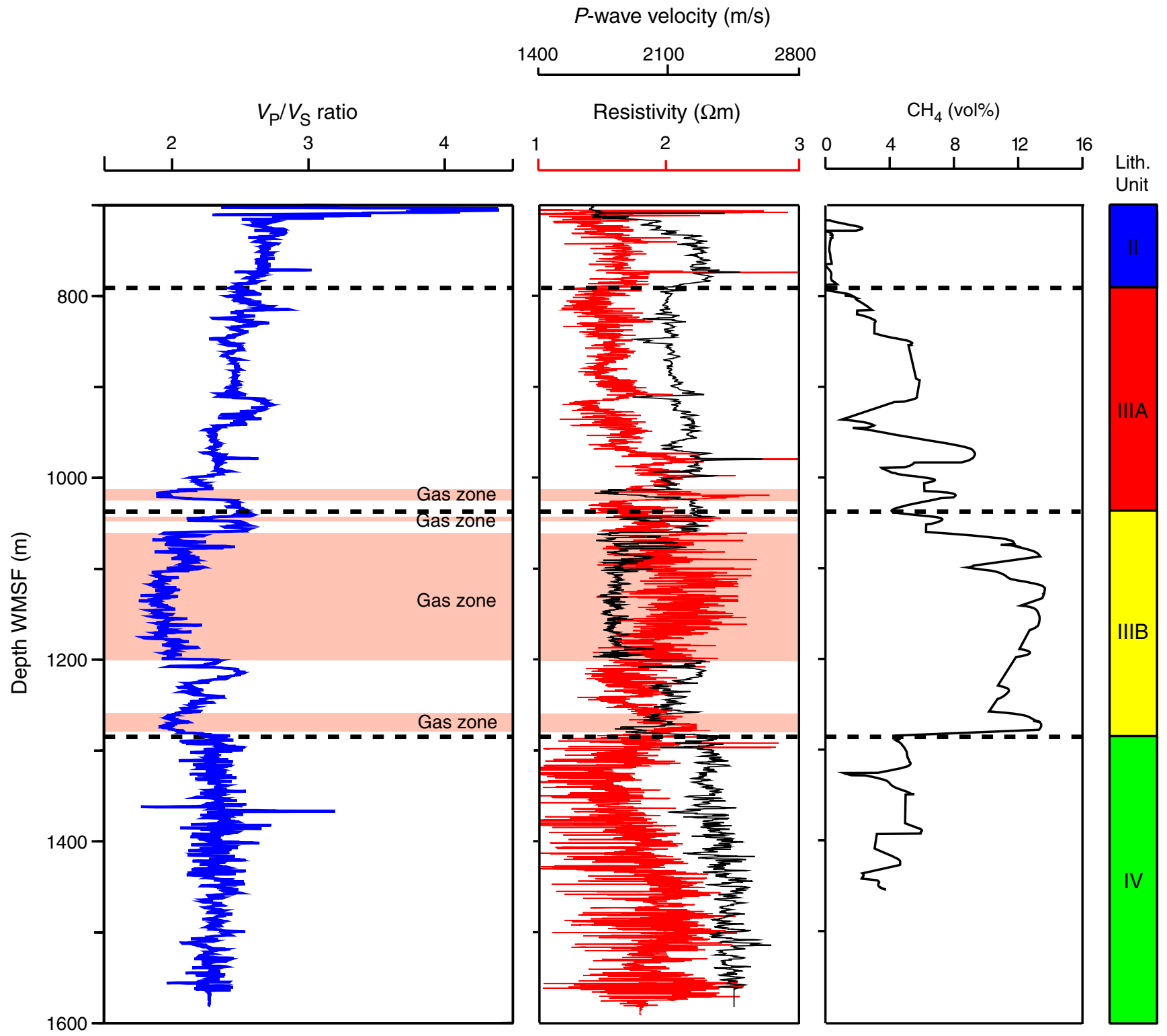


Figure F9. A. Summary of pressure and stress measurements, Site C0009. Blue triangles = pore pressure measurements, orange circles $=$ static mud pressure measurements in the borehole, open square $=$ minimum stress measured by LOT, solid squares = MDT hydraulic fracturing tests. B. Summary of fluid mobility (defined as permeability/fluid viscosity) from single probe MDT tests.

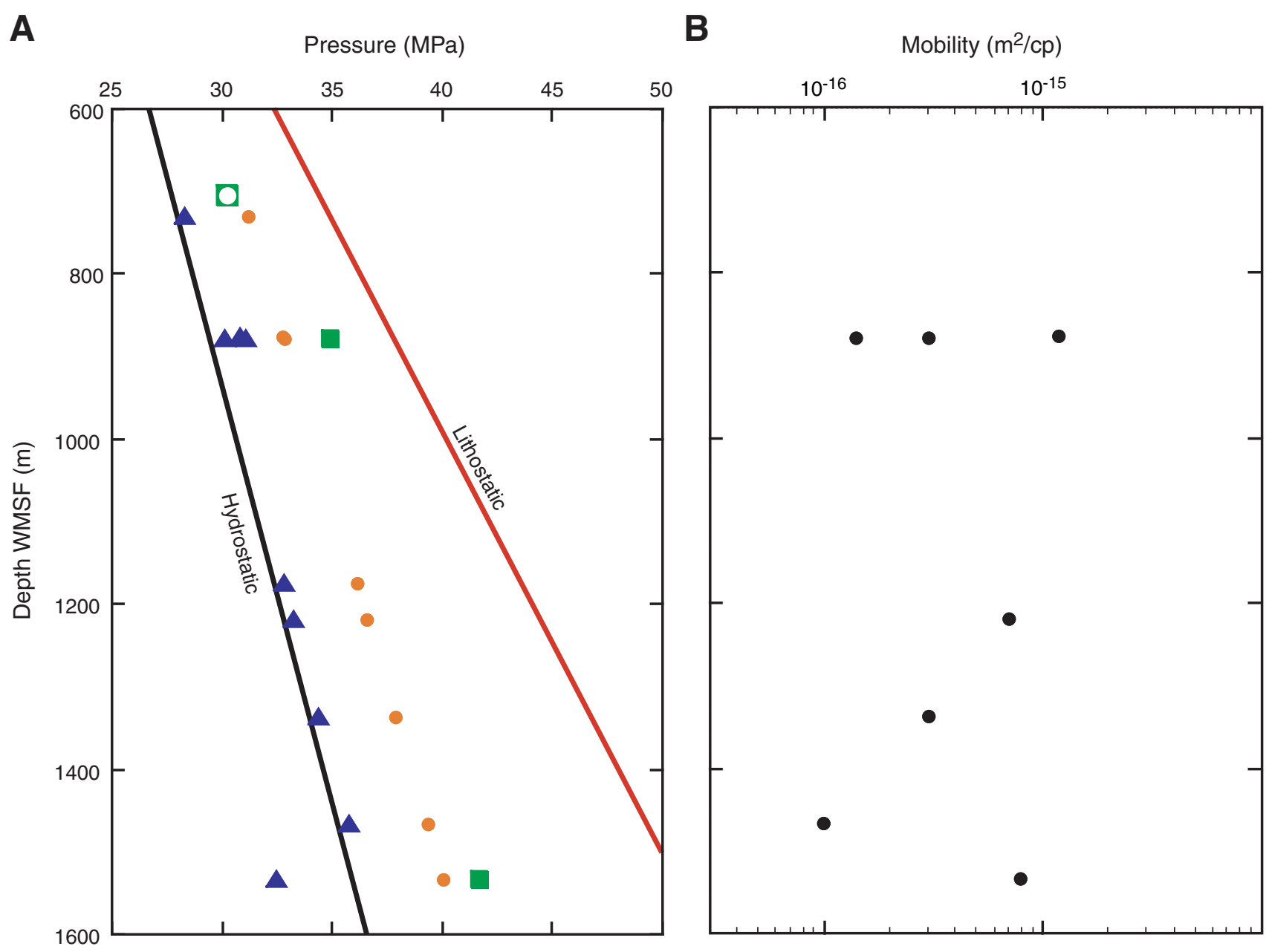


Figure F10. Summary diagram showing LWD/MWD and seismic data, Site C0010. Pink = relogged section. Key elements of casing and hole suspension are shown at right: blue $=$ casing screens, black $=$ casing shoe, thin black $=$ retrievable packer, thin red $=$ smart plug.

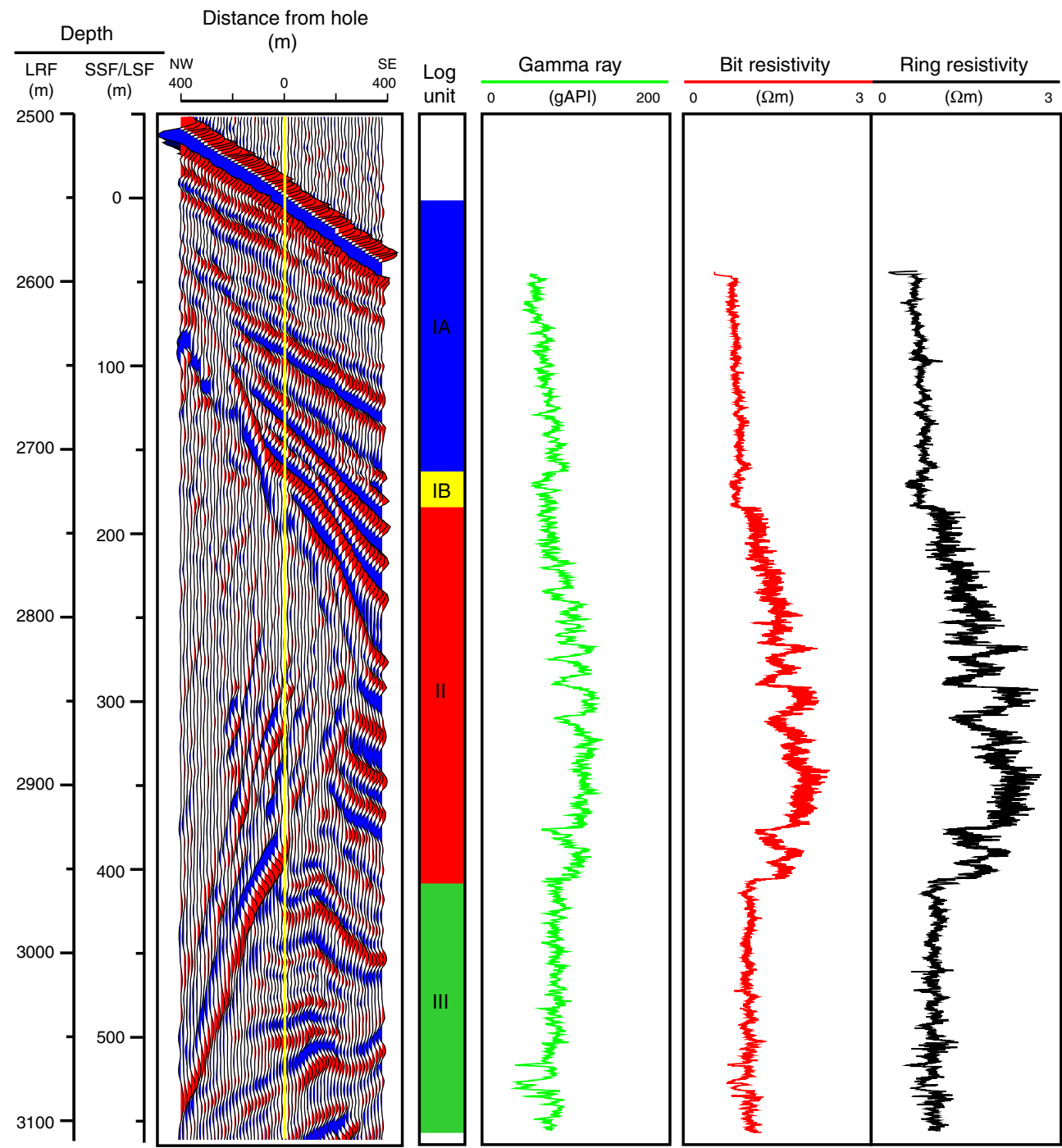

Resistivity image (static)

Resistivity image
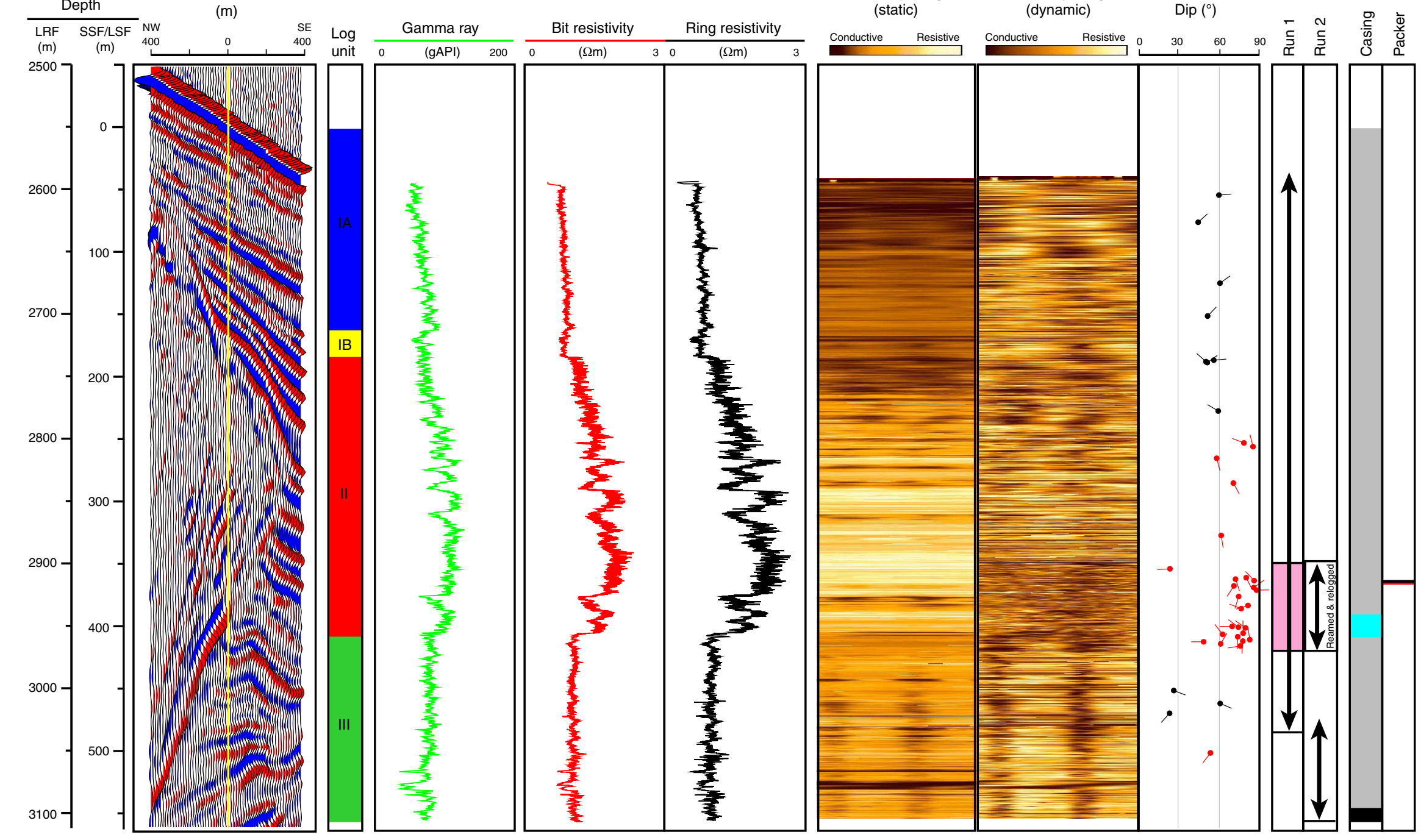

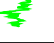

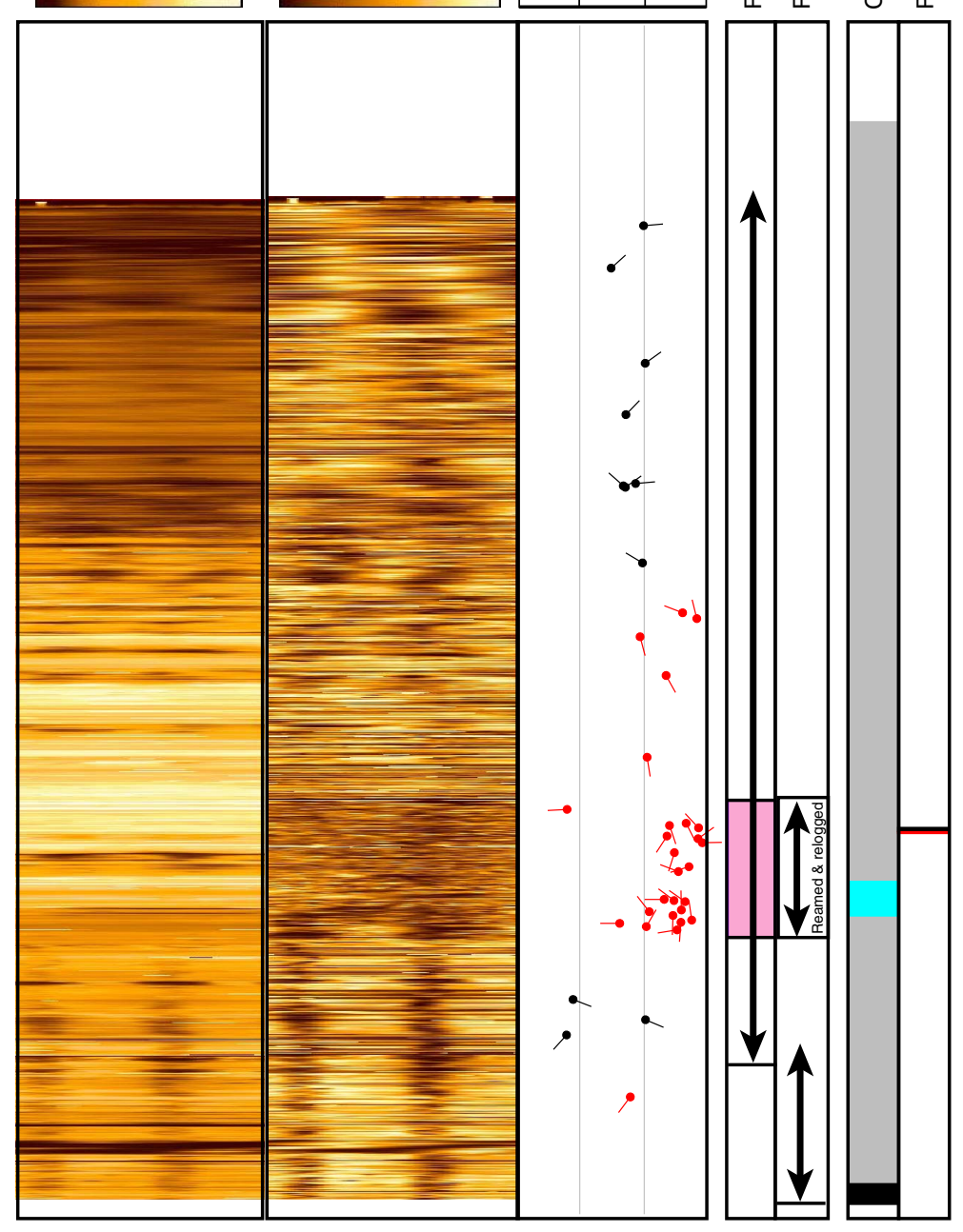

Strata Fractures o 
Figure F11. A. Seismic section between Sites C0004 and C0010. B. Basic interpretation of seismic line. Solid line $=$ seafloor, dashed lines $=$ top and base of the thrust wedge, vertical black lines $=$ borehole locations, gray lines = gamma ray (GR) logs, red lines = resistivity (RES) logs. For Site C0010, logging units are shown; for Site C0004, both logging units (left) and lithologic units defined by coring (right) are shown. Note that the vertical exaggeration (VE) is greater in the interpretative diagram.

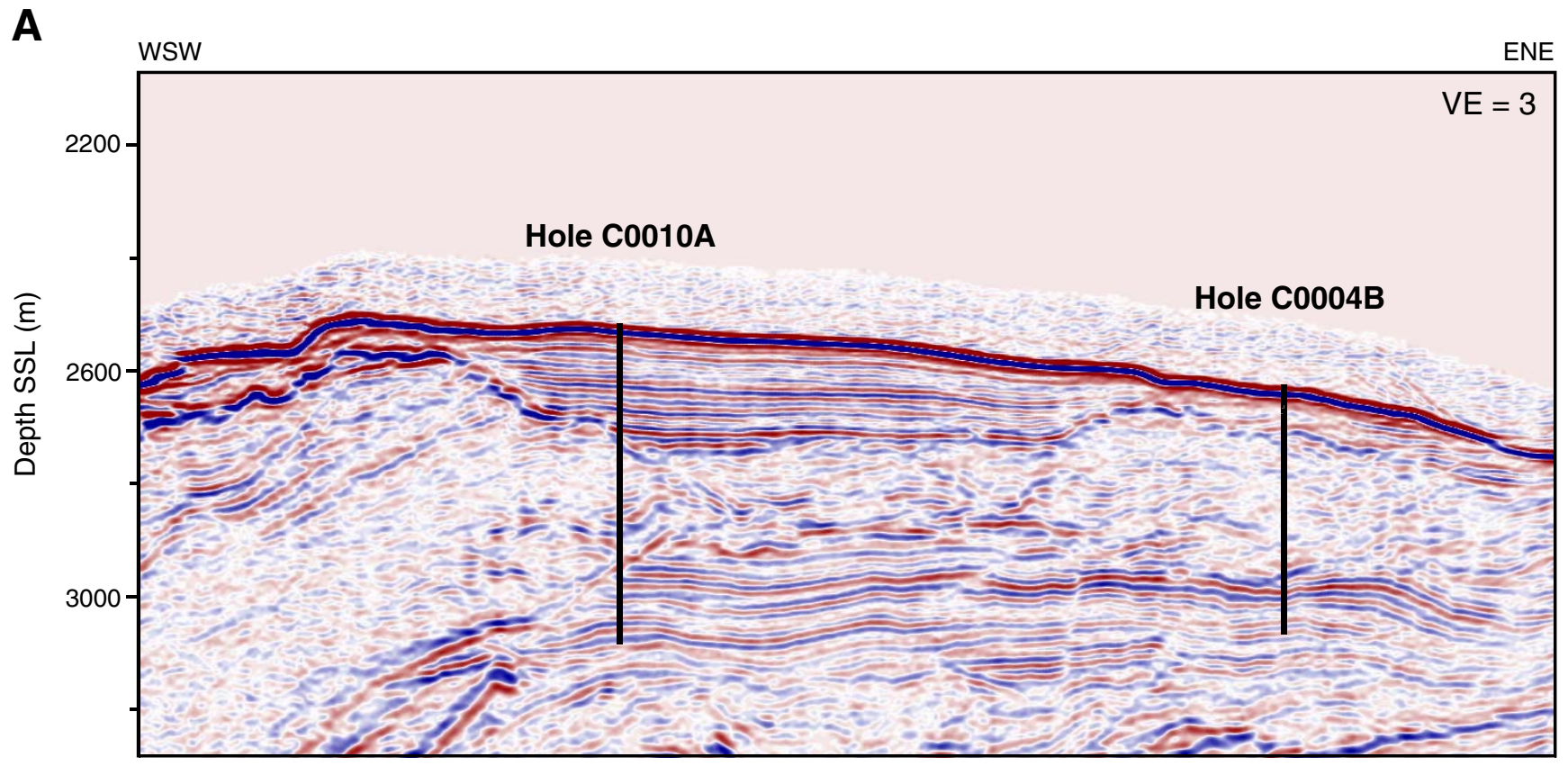

B

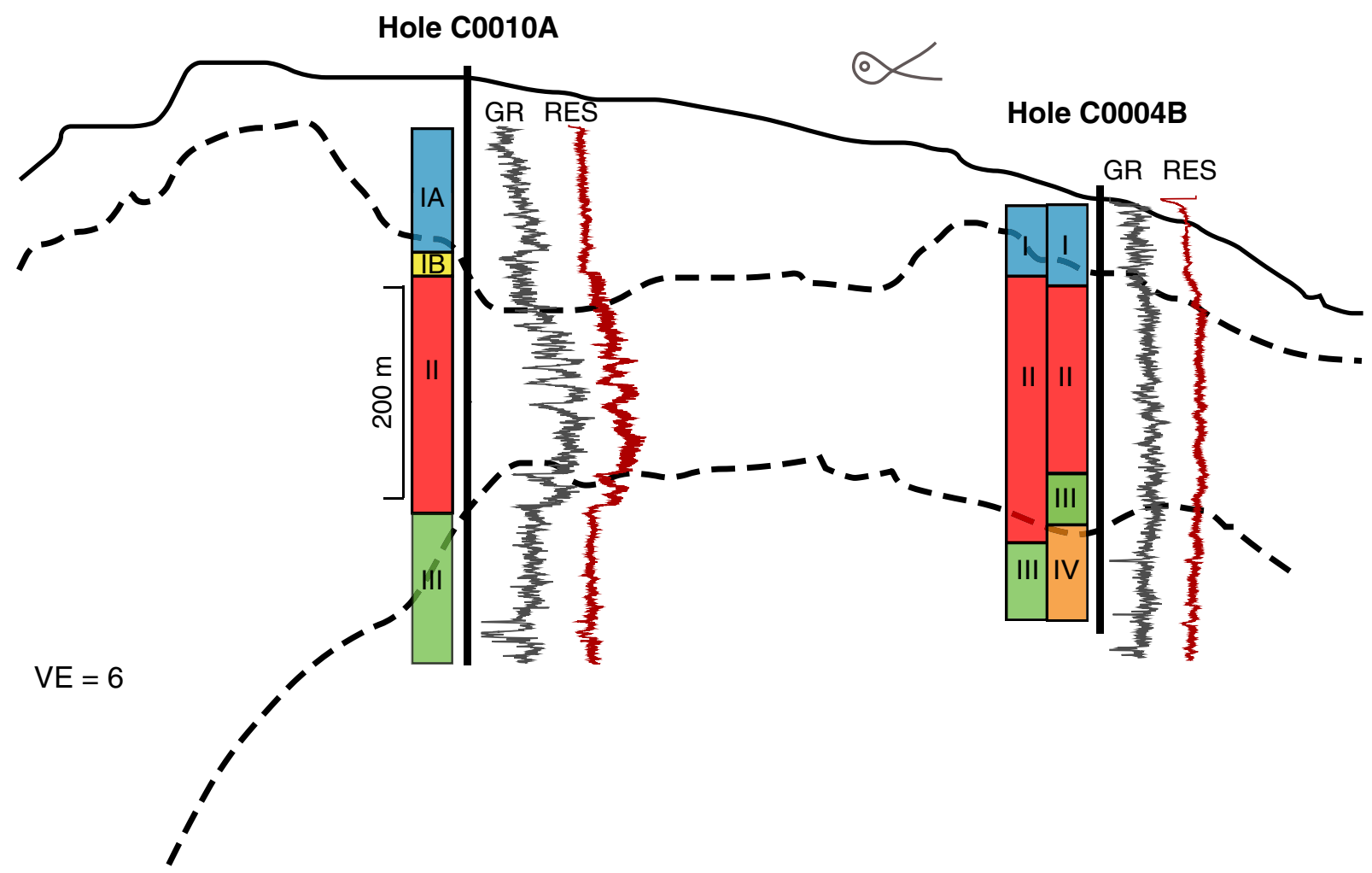


Figure F12. A. Schematic diagram showing dummy run test sensor tree instrument configuration. B. Photos of the dummy run assembly on the rig floor. (Continued on next two pages.)

A

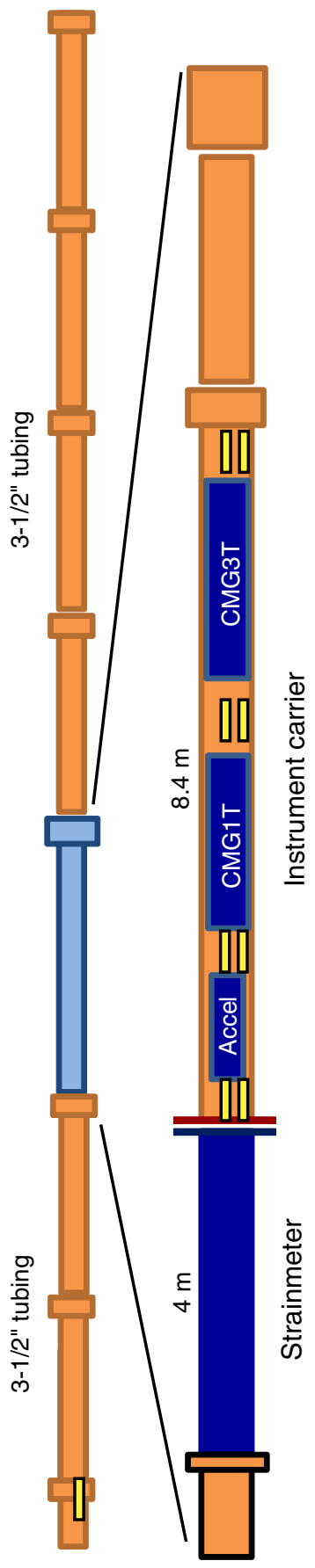

Miniature temperature loggers

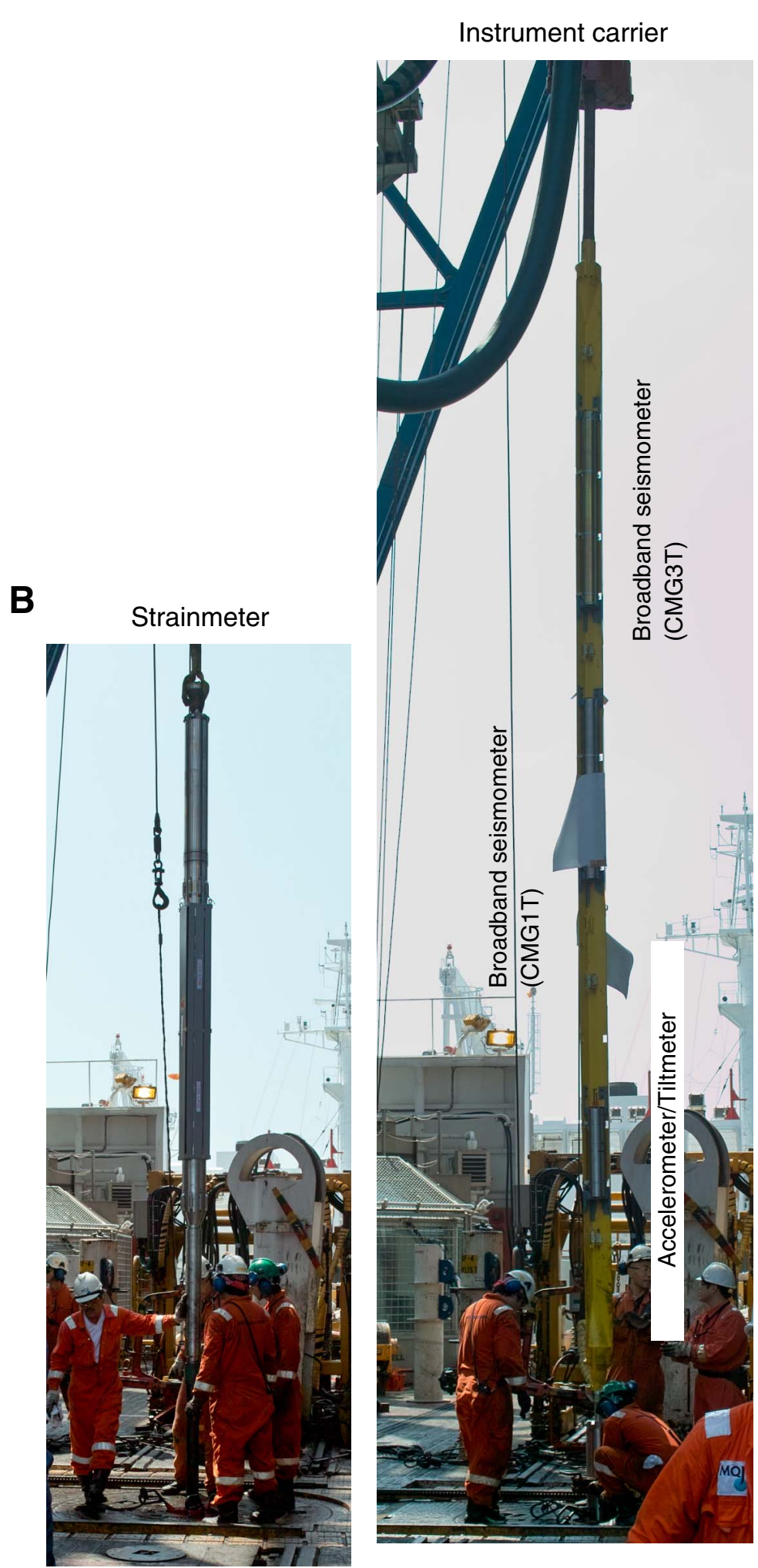


Figure F12 (continued). C. Schematic showing the configuration of screens and sensors for hole suspension. (Continued on next page.)

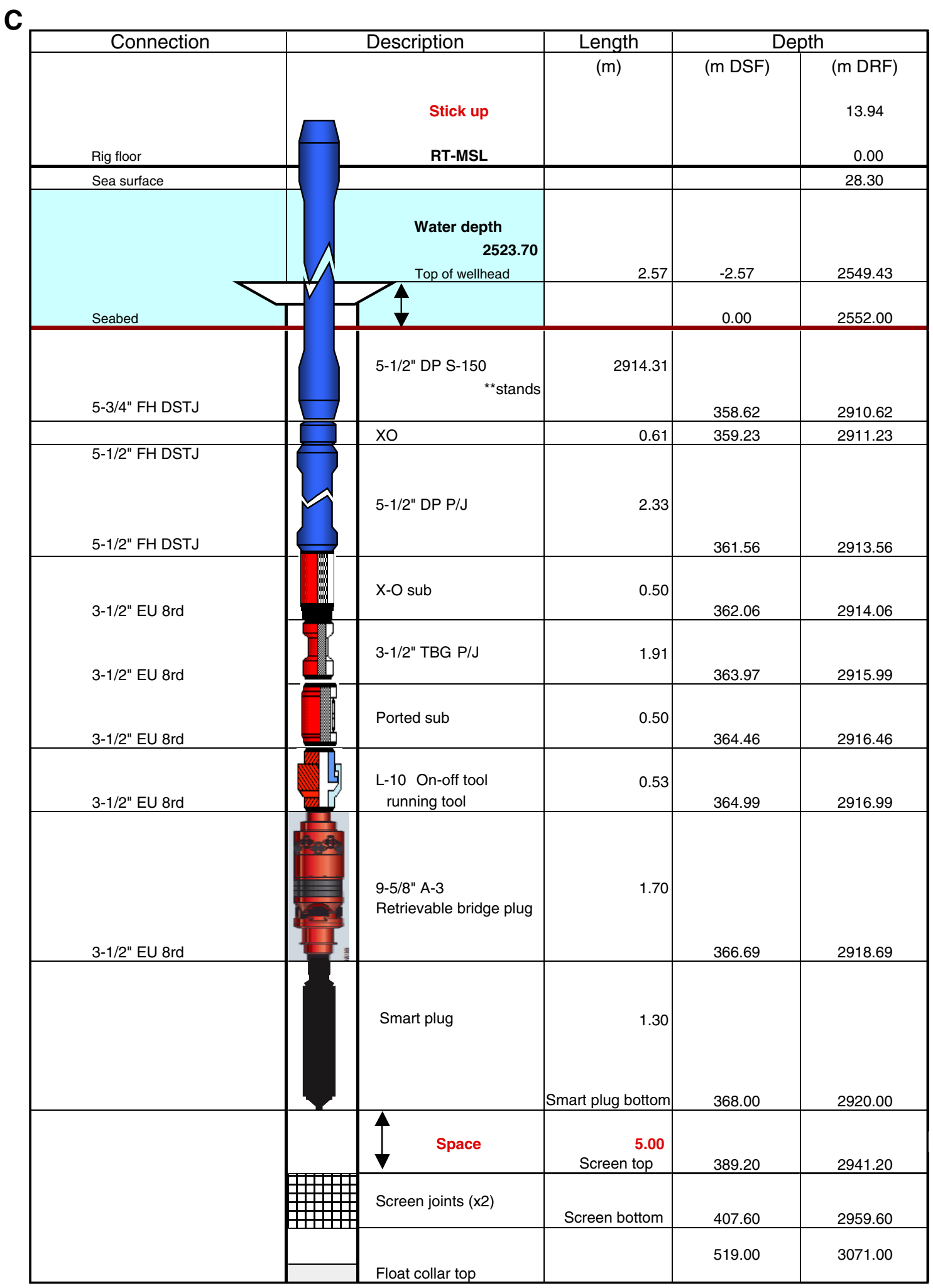


Figure F12 (continued). D. Photo of the smart plug (bottom) and retrievable casing packer (top) shortly before running it to the seafloor for reentry.

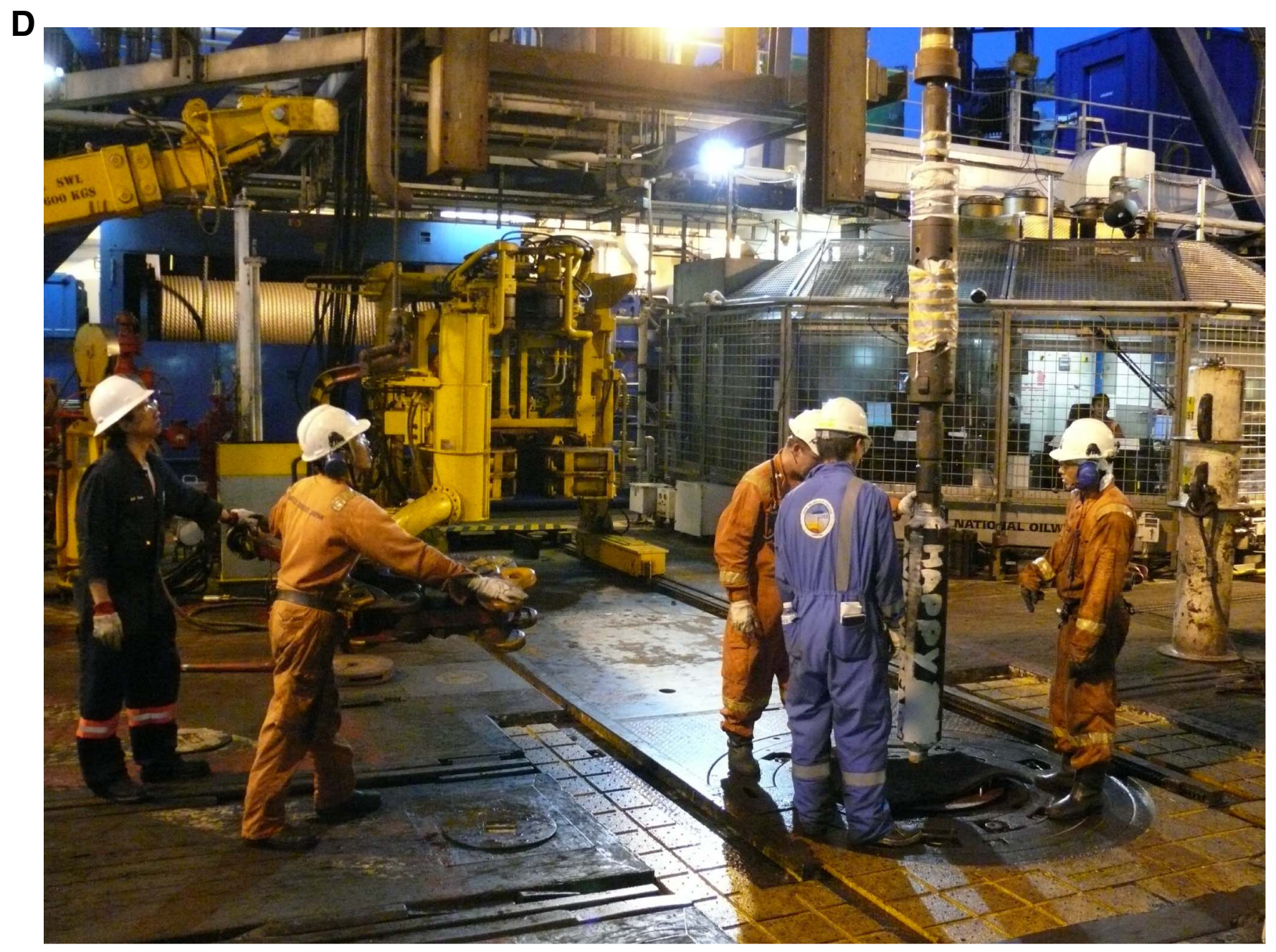


Figure F13. Schematic showing planned long-term observatory configuration. CORK = circulation obviation retrofit kit, ROV = remotely operated vehicle.

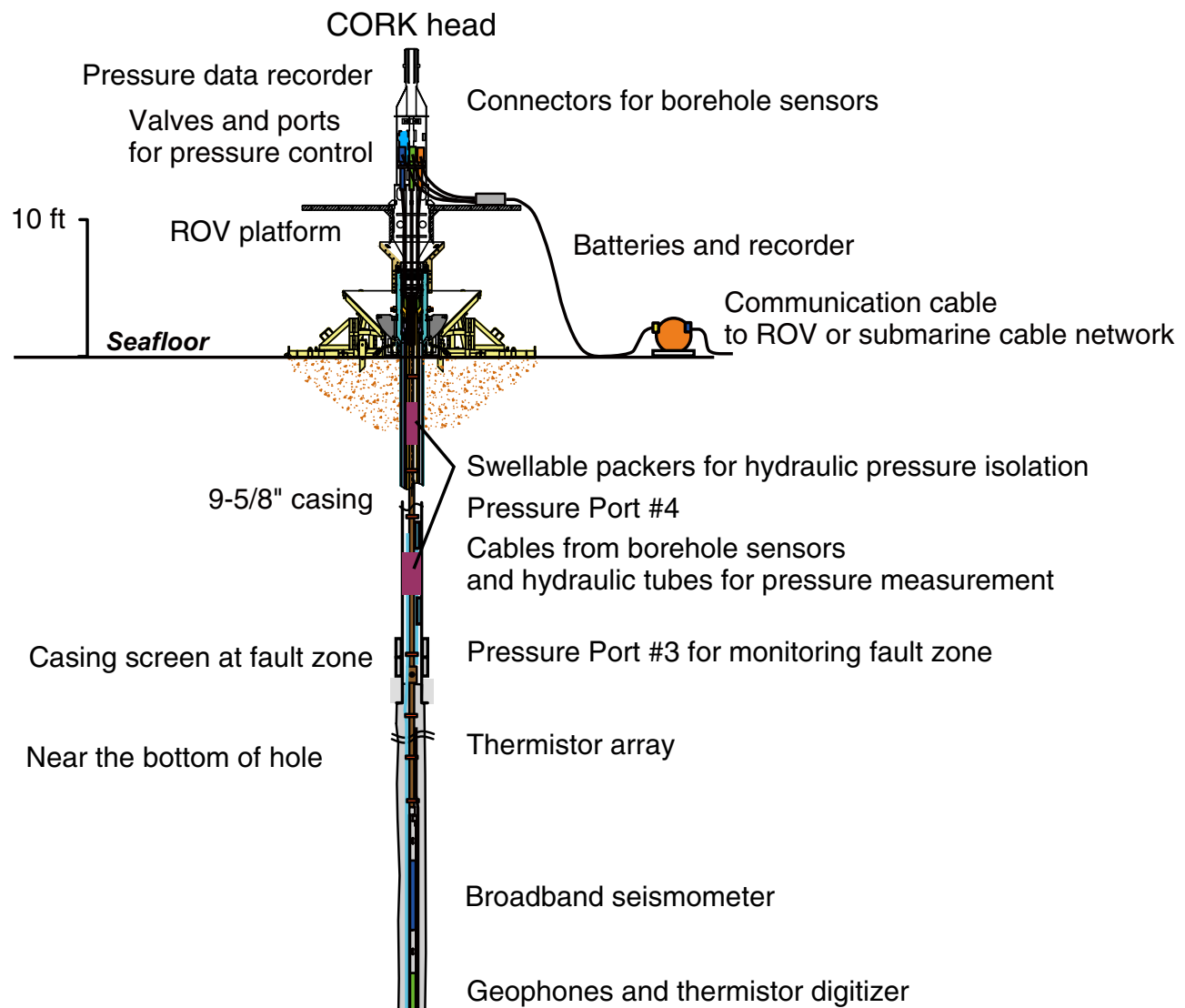

Geophones and thermistor digitizer

Tiltmeter

Strainmeter

Cemented open hole

Pressure Port \#2

(cemented)

Pressure Port \#1

(bottom hole) 
Table T1. Expedition 319 drilling depth terms. (See table notes.)

\begin{tabular}{ll}
\hline $\begin{array}{c}\text { Depth } \\
\text { term }\end{array}$ & \multicolumn{1}{c}{ Depth term explanation } \\
\hline mbsf & meters below seafloor \\
mbsl & meters below sea level \\
DRF & drilling depth below rig floor (rotary table) \\
DSF & drilling depth below seafloor \\
CSF & core depth below seafloor \\
MRF & mud depth below rig floor (used for drilling mud cuttings and gas) \\
MSF & mud depth below seafloor (used for drilling mud cuttings and gas) \\
WRF & wireline log depth below rig floor \\
WMSF & wireline log matched depth below seafloor \\
LRF & LWD depth below rig floor \\
LSF & LWD depth below seafloor \\
SSF & seismic depth below seafloor \\
SSL & seismic depth below sea level
\end{tabular}

Notes: Depth terms are derived from IODP Depth Scales (www.iodp.org/program-policies/). LWD = logging-while-drilling. 
Table T2. Expedition 319 coring summary. (See table notes.)

\begin{tabular}{|c|c|c|c|c|c|c|c|c|c|c|}
\hline Hole & Latitude & Longitude & $\begin{array}{l}\text { Water } \\
\text { depth } \\
(\mathrm{mbsl})\end{array}$ & $\begin{array}{c}\text { Cores } \\
(N)\end{array}$ & $\begin{array}{l}\text { Interval } \\
\text { cored } \\
\text { (m) }\end{array}$ & $\begin{array}{l}\text { Core } \\
\text { recovered } \\
(\mathrm{m})\end{array}$ & $\begin{array}{c}\text { Recovery } \\
\text { (\%) }\end{array}$ & $\begin{array}{c}\text { Drilled } \\
\text { interval } \\
(\mathrm{m})\end{array}$ & $\begin{array}{l}\text { Total } \\
\text { penetration } \\
\text { (m) }\end{array}$ & $\begin{array}{l}\text { Time } \\
\text { on site } \\
\text { (days) }\end{array}$ \\
\hline \multirow[t]{2}{*}{ C0009A } & $33^{\circ} 27.4704^{\prime} \mathrm{N}$ & $136^{\circ} 32.1489^{\prime} \mathrm{E}$ & 2054 & 9 & 84.20 & 57.87 & 68.7 & 1591.8 & 1603.7 & 76 \\
\hline & & \multicolumn{2}{|c|}{ Site C0009 totals: } & 9 & 84.20 & 57.87 & 68.7 & 1591.8 & 1603.7 & 76 \\
\hline \multirow[t]{2}{*}{ C0010A } & $33^{\circ} 12.5981^{\prime} \mathrm{N}$ & $136^{\circ} 41.1924^{\prime} \mathrm{E}$ & 2552 & 0 & \multicolumn{3}{|c|}{ Set casing/observatory testing } & 560.0 & 560.0 & 21 \\
\hline & & \multicolumn{2}{|c|}{ Site C0010 totals: } & 0 & 0.00 & 0.00 & 0.0 & 560.0 & 560.0 & 21 \\
\hline \multirow[t]{3}{*}{ C0011A } & $32^{\circ} 49.73^{\prime} \mathrm{N}$ & $136^{\circ} 52.89^{\prime} \mathrm{E}$ & 4049 & 0 & LWD/MW & & & 952.0 & 952.0 & 5 \\
\hline & & \multicolumn{2}{|c|}{ Site C0011 totals: } & 0 & 0.00 & 0.00 & 0.0 & 952.0 & 952.0 & 5 \\
\hline & & \multicolumn{2}{|c|}{ Expedition 319 totals: } & 9 & 84.20 & 57.87 & 68.7 & 3021.7 & 3105.9 & 102 \\
\hline
\end{tabular}

Notes: $N=$ number. $\mathrm{LWD}=$ logging while drilling, $\mathrm{MWD}=$ measurement while drilling. 